University of Nebraska - Lincoln

DigitalCommons@University of Nebraska - Lincoln

2020

\title{
CEO scanning behaviors, self-efficacy, and SME innovation and performance: An examination within a declining industry
}

Rajiv Nag

François Neville

Nikolaos Dimotakis

Follow this and additional works at: https://digitalcommons.unl.edu/managementfacpub

Part of the Business Administration, Management, and Operations Commons, Management Sciences and Quantitative Methods Commons, and the Strategic Management Policy Commons

This Article is brought to you for free and open access by the Management Department at DigitalCommons@University of Nebraska - Lincoln. It has been accepted for inclusion in Management Department Faculty Publications by an authorized administrator of DigitalCommons@University of Nebraska - Lincoln. 


\title{
CEO scanning behaviors, self-efficacy, and SME innovation and performance: An examination within a declining industry
}

\author{
Rajiv Nag, ${ }^{1}$ François Neville, ${ }^{2}$ and Nikolaos Dimotakis, ${ }^{3}$ \\ 1 Lebow College of Business, Drexel University, USA \\ 2 DeGroote School of Business, McMaster University, Canada \\ 3 College of Business, University of Nebraska-Lincoln, USA \\ Correspondence - François Neville nevillef@mcmaster.ca DeGroote School of Business, \\ McMaster University, 1280 Main Street West, Hamilton, ON, Canada \\ ORCID François Neville http://orcid.org/0000-0002-5759-0502
}

\begin{abstract}
Studying the CEOs of small and medium enterprises (SMEs) in the US metalcasting industry-an industry that has been steadily declining for several years-we develop a theoretical model to examine how CEO scanning behaviors in the form of scanning intensity and proactiveness influence self-efficacy, which in turn influences firm innovation and performance. We extend theory and research by (a) demonstrating of the role and influence of SME CEOs over firm innovation and performance in declining industries, (b) illustrating how scanning provides social learning opportunities for CEOs that enhance their levels of self-efficacy, and (c) showing that self-efficacy mediates the effects of scanning on firm innovation and performance.
\end{abstract}

Keywords: Small business/small and medium enterprises, strategic management, cognition, strategic leadership

Published in Journal of Small Business Management 58:1 (2020), pp 164-199.

doi:10.1080/00472778.2019.1659676

Copyright (C) 2019 International Council for Small Business. Published by Routledge/Taylor \& Francis. Used by permission. 


\section{Introduction}

How do small and medium enterprises (SMEs) innovate and grow while competing in declining industries? This question has recently emerged (Bumgardner, Buehlmann, Schuler, \& Crissey, 2011; Chandler, Broberg, \& Allison, 2014) within a long-standing research tradition that has examined the influence of industry life cycle on SME emergence, performance, and survival (e.g., Chandler \& Hanks, 1994; Covin \& Slevin, 1990; Lumpkin \& Dess, 2001; Short, McKelvie, Ketchen, \& Chandler, 2009; Thornhill \& Amit, 2003). As industries decline, bigger players in the industry move toward the center of the market and further emphasize efficiency and cost leadership (Doz \& Kosonen, 2010; Swaminathan, 1998), thereby placing pressure on SMEs to innovate and change to capitalize on unexploited opportunities (Chandler et al., 2014; Zimmerman \& Zeitz, 2002). As the majority of new business startups generally occur in mature industries (Biery, 2016; Lumpkin \& Dess, 2001), many individuals occupying strategic leadership positions in SMEs (that is, CEOs, owner-managers, founders) will eventually be faced with the task of navigating the realities of industry decline in the hopes of maintaining their firm's competitive position. However, prior research does not delve into understanding the influence of SME strategic leaders over firm innovation and performance in declining industries (for a possible exception, see Beal, 2000). Thus, we refine the question above to ask: How do strategic leaders influence SME innovation and performance in declining industries?

We investigate this question by examining the relationships between how SME CEOs scan their external environment, their self-efficacy, and their firms' innovation and performance. We draw on social learning theory (Bandura, 1977, 1997) and integrate it with the literatures on executive scanning and self-efficacy to articulate our conceptual framework. A core insight of Bandura's $(1977,1997)$ social learning theory - that individuals' self-efficacy forms through engaging in social learning activities - suggests that it may be possible for SME CEOs to undertake certain behaviors that would increase their self-efficacy, which in turn could translate favorably to important strategic outcomes. Executive scanning has been defined as the information search and acquisition behaviors and processes that a firm's strategic leaders engage in (Aguilar, 1967; Hambrick, 1982; Jennings \& Lumpkin, 1992). These behaviors 
create important opportunities for vicarious learning, but can also lead to worrying insights that cast doubt on the future. Self-efficacy - a person's perception of their own capabilities to attain certain high-performance outcomes (Audia, Locke, \& Smith, 2000; Bandura, 1997) - allows individuals to set challenging goals, persist toward the achievement of their goals under adversity, and recover quickly from failure (Bandura, 1997).

Building on these insights, we introduce two related but distinct facets of scanning behaviors, which we label as scanning intensity and scanning proactiveness (Nag \& Gioia, 2012; Parker \& Collins, 2010), and theorize that the two must work in consort to promote a focal CEO's self-efficacy and subsequent firm innovativeness and performance. We test our theoretical arguments on primary data obtained from a fiveyear field study involving CEOs of SMEs operating in the US metalcasting (foundry) industry. As an empirical context for our study, the foundry industry is a compelling setting given its long history and entrenched industry best practices. This industry has seen a steady decline over the past decades and incumbents have faced constraints in terms of chronic manpower shortages, rising competition from low labor cost countries, and stringent environmental regulations.

Consistent with our theorization, we find that SME CEOs, through the joint effects of their scanning behaviors (that is, intensity and proactiveness), can increase their self-efficacy and subsequently influence their firms' innovation and performance. Importantly, we argue and find that congruence between the intensity and proactiveness of a CEO's scanning behavior is positively associated with self-efficacy, but an excess of proactiveness without intensity or of intensity without proactiveness can be counterproductive. We subsequently find that greater levels of CEO self-efficacy significantly influence a focal SME's long-term innovativeness and performance.

Our study makes important contributions to theory and practice. First, our major contribution relates to the literature focused on understanding SME strategy and performance while competing in declining industries by offering a more fine-grained understanding of how strategic leaders can effectively guide innovation and performance within this context. Second, we examine how key social learning behaviors - scanning proactiveness and intensity - influence important firm-level outcomes (that is, innovation and performance through a key intervening 
role of the CEO's self-efficacy). Specifically, our findings highlight the important influence that congruence in intensity and proactiveness of scanning efforts has on self-efficacy. This also directly addresses recent calls for more nuanced and purposeful approaches toward examining how specific behaviors jointly affect self-efficacy beliefs (e.g., Cardon \& Kirk, 2013). Third, a vibrant body of scholarly work has conceived knowledge as a preeminent strategic resource (Grant, 1996; Reus, Ranft, Lamont, \& Adams, 2009). Nonetheless, relatively limited attention has been directed toward understanding how a firm's CEO influences the acquisition and use of knowledge (Felin \& Hesterly, 2007). While environmental scanning has attracted significant scholarly attention as a key managerial activity over the past several years (Daft, Sormunen, \& Parks, 1988; Danneels, 2008; Hambrick, 1982; Jennings \& Lumpkin, 1992), fairly limited work has been done in articulating its role within the conceptual framework of an organization's knowledge management processes (Almeida, Phene, \& Grant, 2003; Choo, 2001; Tsoukas, 2011). In this study we discern a key pathway through which SMECEOs' scanning leads to competitive advantage through their self-efficacy, thereby reinforcing extant realizations that scanning is an important component of a firm's knowledge sensing and acquisition capabilities as a part of its overall dynamic capabilities (Teece, 2014; Zollo \& Winter, 2002). Finally, we extend the current state of understanding of strategic leadership and upper echelons theory. Heeding recent calls (e.g., Hambrick, 2007), our study investigates some of the behaviors and actions that executives accomplish that translate toward strategic outcomes. Altogether, we believe our work offers important practical implications for SME strategic leaders. Our study suggests to these individuals that they need not be defined or constrained by industry conditions or their current levels of self-efficacy - especially if they have low self-efficacy - as they can take actionable measures to improve their self-efficacy and, hence, impact the innovativeness and performance of their firms.

\section{CEO scanning, self-efficacy, and SME innovation and performance: A social learning perspective within a declining industry}

Our primary point of departure is to conceive scanning as a crucial behavioral antecedent to SME CEO self-efficacy; that is, CEOs' task-specific confidence about their own capabilities to undertake actions and 


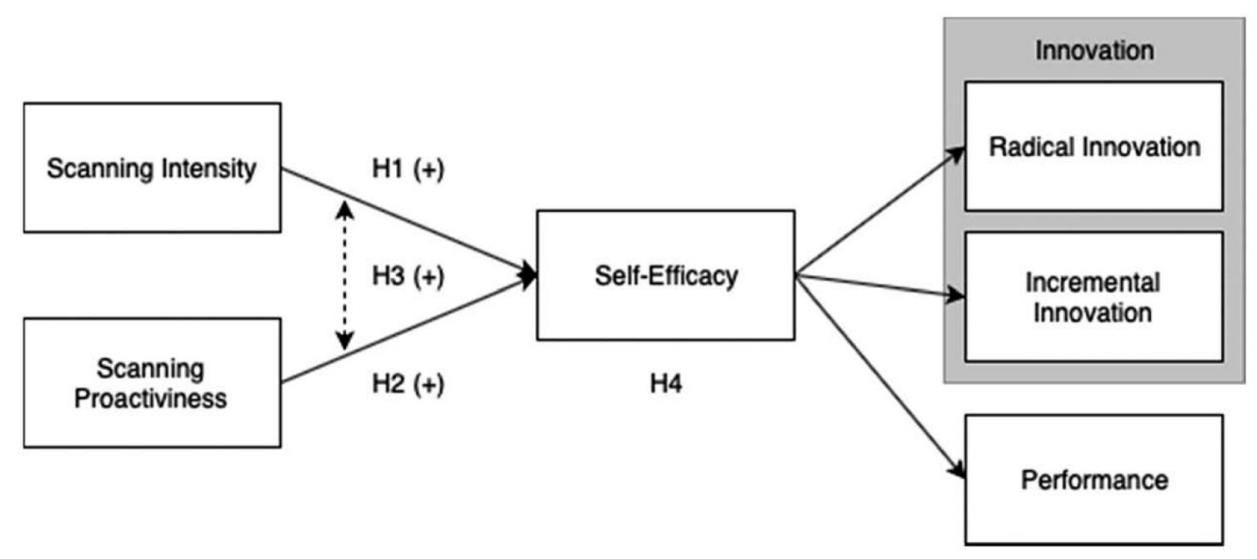

Figure 1. Conceptual model of research hypotheses.

attain performance outcomes (Audia et al., 2000; Bandura, 1997). These beliefs in turn form a crucial enabler of actions that SME CEOs engage in, which subsequently lead to firm innovation and performance. We invoke social learning theory (Bandura, 1977, 1997) as a guiding framework to theorize that self-efficacy becomes an important intermediary in linking the scanning activities of SME CEOs to firm innovation and performance. We adopt a broad conception of scanning as reflected in two related but distinct components: scanning intensity, which reflects the amount of effort expended to collect information, and scanning proactiveness, which encapsulates the activities through which CEOs intrude into the environment to derive superior and distinctive information in a proactive as opposed to a reactive sense. Intensity reflects scanning that is broad, effortful, and sustained while proactiveness represents undertaking these efforts ahead of time, as opposed to as a reaction to an event already in place or as a last-minute search for unlikely solutions. Figure 1 depicts the conceptual model that we advanced in this study.

\section{Scanning}

Nearly five decades ago, Mintzberg (1968, p. 224) identified managers as the nerve centers of organizational information. Since then, a significant literature has accumulated under umbrella terms such as environmental scanning and boundary spanning (Boyd \& Fulk, 1996; Hambrick, 1982; Leifer \& Delbecq, 1978). This literature has established 
that the amount and focus of environmental scanning carried out by strategic leaders has a significant influence on firm performance (Daft et al., 1988; Garg, Walters, \& Priem, 2003). Relatedly, a parallel literature locates scanning as a necessary antecedent to a firm's dynamic capabilities (Danneels, 2008; Teece, 2007; Zollo \& Winter, 1999). Dynamic capabilities are defined as "the firm's ability to integrate, build, and reconfigure internal and external competences to address rapidly changing environments" (Teece, Pisano, \& Shuen, 1997, p. 516). Scanning activities focused on the firm's environment are viewed as the elemental first steps in the broader process of knowledge acquisition that eventually leads to superior innovation-related outcomes (Katila, 2002; Teece, 2007). Recently, this stream of research has explored deeper cognitive activities of acquiring and processing information that drives interfirm heterogeneity in capabilities of sensing and shaping innovation and growth opportunities (Helfat \& Peteraf, 2015; Hodgkinson \& Healey, 2011; Salvato \& Rerup, 2011). Our study offers a step in this direction, particularly in contexts marked by industry decline.

Seeking and acquiring information about the environment has long been considered a key activity carried out by a firm's key strategic leaders (Ansoff, 1975; Etzioni, 1967). Aguilar provided an early formal definition of scanning as an "activity of acquiring information about events and relationships in a company's outside environment, the knowledge of which would assist top management in its task of charting the company's future course of action" (1967, p. 1). Subsequent conceptualizations of scanning have varied from relatively narrow conceptions of scanning as a process that provides data about the external environment to managers (Daft \& Weick, 1984; Elenkov, 1997) to others that locate scanning within the broader ambit of concepts such as learning, boundary spanning, coping with the environment, and decision-making (Dollinger, 1984; Leifer \& Delbecq, 1978). Scanning has been variously defined as behaviors that individuals in strategic leadership positions engage in to collect data, information, and insights (see Table 1 for a list of operating definitions from a selection of key scanning articles).

Despite this variety, relatively little work has looked into the activities and behaviors that entrepreneurs and other strategic leaders tasked with starting and running SMEs (that is, CEOs, owner-managers, founders) engage in while scanning their external and internal environments. A larger part of the empirical work on scanning activities has adopted a 
Table 1. Definitions of executive scanning, a representative selection.

\begin{tabular}{|c|c|}
\hline Authors & Definitions \\
\hline Aguilar (1967) & $\begin{array}{l}\text { "Activity of acquiring information about events and } \\
\text { relationships in a company's outside environment, the } \\
\text { knowledge of which would assist top management in its } \\
\text { task of charting the company's future course of action." } \\
\text { (p. 1) }\end{array}$ \\
\hline Hambrick (1981) & $\begin{array}{l}\text { "Scanning - the process of learning about events and } \\
\text { trends in the organization's environment." (p. 256) }\end{array}$ \\
\hline Etzioni (1986) & $\begin{array}{l}\text { "The term scanning is used to refer to search, collection, } \\
\text { processing, and evaluation of information as well as to } \\
\text { the drawing of conclusions, all elements in the service of } \\
\text { decision making." (p. 8) }\end{array}$ \\
\hline Daft and Weick (1984) & $\begin{array}{l}\text { "Scanning is defined as the process of monitoring the } \\
\text { environment and providing the environmental data to } \\
\text { managers. Scanning is about data collection." (p. 286) }\end{array}$ \\
\hline Cowan (1986) & $\begin{array}{l}\text { "Scanning allows for the input of new information which } \\
\text { alters one's conception of reality." (p. 770) }\end{array}$ \\
\hline Ghoshal (1988) & $\begin{array}{l}\text { "Environmental scanning is the activity by which } \\
\text { organizations collect information about their } \\
\text { environments." (p. 69) }\end{array}$ \\
\hline Thomas, Clark and Gioia (1993) & $\begin{array}{l}\text { "Scanning involves information gathering; it usually is } \\
\text { considered an antecedent to interpretation and action." } \\
\text { (p. } 240 \text { ) }\end{array}$ \\
\hline Danneels (2008) & $\begin{array}{l}\text { "Environmental scanning refers to the extent to } \\
\text { which organization members devote their efforts to } \\
\text { learning about events and trends in their organization's } \\
\text { environment." (p. 524) }\end{array}$ \\
\hline Kor and Mesko (2013) & $\begin{array}{l}\text { "Managers utilize environmental scanning to identify new } \\
\text { trends and opportunities, and integrate new ideas and } \\
\text { knowledge with the firm's existing capabilities, which is } \\
\text { instrumental." (p. 233) }\end{array}$ \\
\hline
\end{tabular}

quantity-based approach (that is, often operationalized as frequency or intensity of scanning) instead of exploring the specific activities that individuals in strategic leadership positions engage in to create qualitatively superior information about their environment (for example, Beal, 2000). We surmise that viewing scanning as fundamentally an information collection exercise on the part of strategic leaders renders them as passive recipients of environmental stimuli, thereby denying the agentic latitude inherent in the scanning activity. There is a need to depart from the dominant emphasis on the quantity and refocus our attention on the true scope of the scanning concept as explored in the early work 
of Aguilar (1967), who empirically identified four modes or types of scanning activity; namely, undirected viewing, conditioned viewing, informal search, and formal search. Daft and Weick (1984) expanded on this view by introducing a crucial element that they termed as an organization's intrusiveness in the environment. The notion of organizational intrusiveness relates to the fundamental process of enactment wherein managers' actions impose structures of meaning on their surroundings, thereby literally creating the very environments in which they operate (Weick, 1979).

Supplanting a passive view of scanning with a proactive conception entails shifting the focus from the amount of data collected to those activities that aid SME CEOs in generating novel insights and plausible opportunities to exploit. Whereas the former assumes that information is freely available to all leaders and it is just the differences in data collection efforts that can influence the strategic advantage that scanning can provide, the latter is based on the argument that managers have to act on their environments to obtain qualitatively better information relative to their counterparts.

Our concept of scanning proactiveness draws support from growing research that has explored proactive behavior as a personality correlate, particularly in contexts such as effective work design, job performance, supervisor-employee relationships, and career success (Crant, 2000; Crant \& Bateman, 2000; Grant \& Ashford, 2008). In this stream of work, proactive behavior has been defined as the dispositional tendency to effect environmental change (Bateman \& Crant, 1993). Grant and Ashford, in a comprehensive review of this emerging stream, broadened the definition of proactivity as "anticipatory action that employees take to impact themselves and/or their environments" (2008, p. 8). A key insight from Grant and Ashford's (2008) conceptualization of proactivity is its futuristic/anticipatory characteristic. It can be argued, for instance, that scanning activities aimed at identifying new and uncertain opportunities are likely to motivate different actions than those aimed at keeping track of known contingencies (Daft \& Weick, 1984; Etzioni, 1967; Pryor, Webb, Ireland, \& Ketchen, 2016; Shane, 2000; Sleptsov \& Anand, 2008). Along these lines, Nag and Gioia (2012) show the importance of proactive scanning, beyond simply how often managers scan their environments. Also, prior work on the influence of proactive personality in entrepreneurship demonstrates that proactive personality is positively associated with individuals' entrepreneurial intentions (Crant, 1996). 
In the context of small business management, Becherer and Maurer's (1999) study on small company presidents revealed that proactive personality was related to the entrepreneurial posture of the firm and to its performance. Along similar lines, Kickul and Gundry (2002) found a direct relationship between a small firm owner's proactive personality and the firm exhibiting a prospector strategic orientation.

The idea of scanning proactiveness also shares conceptual linkages with research on entrepreneurial orientation (Covin \& Slevin, 1991; Miller, 1983; Naldi, Nordqvist, Sjöberg, \& Wiklund, 2007) that has conceptualized proactiveness as an important component of entrepreneurial behavior (Barringer \& Bluedorn, 1999; Lumpkin \& Dess, 1996; Yoo, 2001). The proactiveness dimension of entrepreneurial orientation refers to "seeking new opportunities which may or may not be related to the present line of operations" (Venkatraman, 1989, p. 949) and "seizing initiative and acting opportunistically in order to shape the environment" (Lumpkin \& Dess, 1996, p. 147).

We posit that the concept of scanning proactiveness helps in tapping specifically into the information-seeking aspect of the overarching proactiveness dimension of entrepreneurial orientation. Prior research has provided strong grounds for exploring the relationship between environmental scanning and corporate entrepreneurship (Yoo, 2001; Zahra, 1991). Barringer and Bluedorn (1999, p. 423) note that "environmental scanning facilitates the risk-taking and proactiveness dimensions of entrepreneurial behavior." They further argue that scanning serves as a means for uncertainty absorption that reduces the perceived riskiness of innovative decisions and entrepreneurial actions, thereby enhancing the proclivities of CEOs to engage in such actions. Interestingly, these studies have tended to consider and measure only the "intensity" facet of environmental scanning, thereby leaving unaddressed the importance of the "quality" of information that the scanning activity needs to generate to drive the entrepreneurial actions and outcomes in focus.

Additionally, research on environmental scanning has tended to focus more on large and established firms. Those studies that have examined smaller firms have focused on proactive personality as a disposition or proactiveness as a larger, firm-level orientation, rather than looking at proactive scanning behaviors or activities per se. Arguably, proactive scanning activities can also be expected to be a vital behavior for SMECEOs who have to identify opportunities for innovation and growth, particularly while their industries are in decline. Hence, a key opportunity 
for strengthening the explanatory power of scanning resides not only in accounting for variations in the intensity of scanning behaviors, but also in understanding how specific behaviors that represent the quality of scanning, such as its proactiveness, may fundamentally relate to SME strategic leadership and innovation and growth outcomes.

\section{Self-efficacy}

An important concept linking SME CEO scanning behaviors to performance outcomes is self-efficacy. Self-efficacy has been described as "beliefs in one's capabilities to organize and execute the courses of action required to produce given attainments" (Bandura, 1997, p. 3; see also Audia et al., 2000). It represents an important indicator of possible action due to its influence on the conclusions that one draws relative to the potential and expectations of future actions (Bandura, 1997; Baum\& Locke, 2004), both directly and indirectly. Directly, it affects individual perception on whether a set course of action might be successful, whereas indirectly it determines individual perception of how challenging the current situation is, further coloring perceptions of likelihood of success for each action (Izard, 1993; Lazarus \& Folkman, 1984).

Self-efficacy thus represents an important enabler of action within the SME CEO's role. Concretely, low self-efficacy can indicate to the individual that any given behavior or course of action is unlikely to be successful; in turn, this unfavorable evaluation will reduce the likelihood that such behavior will even be attempted (Bandura, 1982). High self-efficacy, conversely, increases the perceived likelihood of success and empowers the individual to undertake the action under consideration (Chen, Greene, \& Crick, 1998). Furthermore, such action is likely to be engaged in with increased persistence and resilience (Bandura, 1997; Stajkovic \& Luthans, 1998). Even more generally, self-efficacy is associated with the situations that individuals seek or avoid, which can affect the behavioral context in an even deeper fashion (Wood \& Bandura, 1989).

While the importance of the relationship between self-efficacy and behavior has been demonstrated in a number of contexts (see Judge \& Bono, 2001; Judge, Jackson, Shaw, Scott, \& Rich, 2007; Stajkovic \& Luthans, 1998), self-efficacy levels are particularly important for entrepreneurs and strategic leaders of SMEs because "an individual with high self-efficacy for a given task will exert more effort for a greater length of 
time, persist through setbacks, set and accept higher goals, and develop better plans and strategies for the task" (Shane et al., 2003, p. 267). Relatedly, Boyd and Vozikis (1994) argue that self-efficacy is likely to be an important driver of entrepreneurial intentions and actions.

\section{The scanning intensity-self-efficacy relationship}

CEOs' scanning activities can be seen as key components of learning at the organizational level. Indeed, in developing the notion of "learning organization" as a necessary complement to an organization's entrepreneurial orientation, Slater and Narver (1995) viewed information acquisition as a key initiating factor of organizational learning.

By scanning the firm's external environment, and thus acquiring and using information about events, trends, and relationships that are relevant to the firm, SME CEOs stand to gain valuable insights. These insights can then serve to enhance perceptions of their ability to articulate and implement strategic initiatives (Auster \& Choo, 1994). Because SME CEOs' task requirements often change based on developments in the firm's external environment, scanning is also likely to allow them to anticipate future task requirements, which would mitigate the risk of forming inaccurate efficacy beliefs (see Audia et al., 2000). Further, the act of scanning for information, in and of itself, can constitute a source of confidence in understanding strategy-performance links (for example, Audia et al., 2000; March \& Olsen, 1976).

Self-efficacy beliefs are formed through four main processes of social learning (Bandura, 1977): vicarious experiences, relating to experiencing someone else's successes or failures; enactive mastery experiences, relating to experiencing one's own successes or failures; social persuasion, in which individuals are convinced of others about their competence or lack thereof; and physiological or emotional reactions, which relate to examining one's own states (such as anxiety) for information about their overall capabilities (Bandura, 1982, 1986, 1997; Gist \& Mitchell, 1992). Of these four, we expect that SME CEOs' scanning activities will impinge primarily on vicarious experience, mastery experience, and physiological reactions. ${ }^{1}$

1 We surmise that social persuasion will be a less relevant process in this case, as the functions inherent in persuasion (such as other individuals or groups convincing the focal CEO that they are able to accomplish a task) are not part of the scanning domain. 
Vicarious experiences enhance self-efficacy by providing cues to an individual that relevant others have succeeded in similar contexts, and by illustrating the behavioral repertoires that have allowed such success (Bandura, 1997; Gist \& Mitchell, 1992). Higher levels of scanning on the part of the CEO would plausibly be associated with greater possibilities for vicarious experiences, as the information acquired in other contexts would provide valuable insights on what has previously worked for others, thereby demonstrating to the CEO that such actions are possible in general and for him or her specifically (for example, Baum, Li, \& Usher, 2000; Kim \& Miner, 2007; Leblebici, Salancik, Copay, \& King, 1991; Shane, 2000).

While scanning has not typically been related to actual job-related enactive mastery experiences (that is, it does not necessarily have to do with performing one's core or traditional job responsibilities), in the context of SME management and leadership, it can still enhance selfefficacy through the accomplishment of the scanning task, as information processing is a core function for such individuals (Ansoff, 1975; Cooper, Folta, \& Woo, 1995; Hambrick, 1982; Mintzberg, 1968). The resulting confidence in one's information-gathering skills can manifest as increased self-efficacy through enactive mastery experiences as a consequence of which a CEO develops positive perceptions about their ability to understand the firm and its external and internal environment (Audia et al., 2000). More objectively, greater levels of knowledge are expected to increase one's potential for high levels of performance (or at least, reduce one's expectations of ignorance-based mistakes), which will be associated with increased levels of self-efficacy (Wood \& Bandura, 1989).

Finally, the purposeful exposure to a variety of contexts that scanning brings about can also reduce expected future anxiety (or other negative reactions) that unexpected events can cause, thus maintaining individual self-efficacy in the face of adversity (Inzana, Driskell, Salas, \& Johnston, 1996). Scanning might uncover unfavorable information or looming threats and at low levels of scanning, these experiences will be novel, shocking, and surprising, thus becoming a source of distress to the SME CEO and reducing their self-efficacy beliefs; this is in line with work showing that anxious executives might be reluctant to take risks in their strategies (Mannor, Wowak, Bartkus, \& Gomez-Mejia, 2016). As scanning levels increase, however, the novelty of the unfavorable experiences encountered is reduced, and with it the adverse distress reactions, 
because the CEO is likely to become habituated to them, avoiding self-efficacy losses. In sum, higher levels of scanning intensity are expected to facilitate social learning and increase self-efficacy while an SME is competing in a declining industry. We thus expect that:

Hypothesis 1 (H1): SME CEO scanning intensity will be positively associated with CEO self-efficacy.

\section{The importance of congruence between scanning intensity and proactiveness}

Although we argued that the amount or intensity of scanning will be associated with SME CEOs' self-efficacy, an important consideration needs to be accounted for. Prior research suggests that characteristics of information available to an individual can influence their perceptions of self-efficacy (Bandura, 1986; Earley \& Erez, 1991). For instance, Cervone and Peake (1986) found that individuals exposed to information with high anchor values perceived greater levels of self-efficacy. Furthermore, research has also found that information cues about future expectations and normative performance comparisons are key influencers in persuading individuals about their self-efficacy levels (Earley, 1994). These insights suggest that those scanning activities by which SME CEOs intrude into their environments, seek information about prospective opportunities, and obtain comparative performance cues are likely to play an important role in persuading them about their own abilities to succeed. It matters not only how intensely CEOs scan the environment, but also the temporal context in which they undertake these activities.

As presented, the arguments above reflect the effects of intensity at a given (mostly average) level of scanning proactiveness. To the extent that people engage in scanning behaviors whose intensity is more incongruent with the proactiveness of said behaviors, our predictions above based on the self-efficacy boosting effects of vicarious learning, mastery experiences, and physiological responses would not hold. That is, while intense scanning is expected (for a reasonable level of proactiveness) to offer self-efficacy benefits, such benefits might be moderated by the congruence of these effects with the actual proactiveness with which they are manifested. 
Scanning that is more proactive in nature focuses on possible future states, with a more open temporal horizon and a relatively unrestricted framework for the search. This is so because proactive scanning (compared to nonproactive scanning) offers a greater scope for social learning via experimentation, modeling behaviors at higher performance levels, and engaging with the environment in ways that can help actively shape it instead of simply reacting to it (Bandura, 1986; Schwandt, 2005). We expect that when a CEO engages in scanning that is congruent in its proactiveness and intensity, self-efficacy benefits will be magnified; when a CEOs engages in scanning that is more intense than it is proactive, no such benefits will occur. Similarly, proactive scanning that is not also high in intensity will not produce comparable self-efficacy benefits.

There are several reasons driving this argument. First, to the extent that higher proactiveness results in a search that is not stressor or context driven, search patterns can be more systematic, thorough, and nonreactive (Keinan, 1987), and provide a greater potential for learning (Parker \& Sprigg, 1999). When combined with a high level of scanning intensity, this offers a larger possibility of allowing for mastery and vicarious experiences described above. Simply, being similarly proactive and intense in one's scanning efforts provides more opportunities and time to learn. Intense scanning can provide a wide range of information; this information, however, can be argued to have relatively little value unless actively processed in the mind of an individual (Alavi \& Leidner, 2001).

Therefore, the proactiveness of scanning forms a basis for building knowledge as it triggers a cognitive process through which new stimuli are given meaning in a systematic and organized way that would not be realized with less proactive efforts. Likewise, high scanning proactiveness coupled with low intensity scanning intensity does not create sufficient opportunities for learning, as the level of intensity is just not high enough. In addition, scanning proactiveness provides a greater latitude to seek out more relevant contexts, which allows for more vicarious experiences and enactive mastery opportunities. Proactive scanning is further likely to diverge from established routines by examining novel areas of course of action; this divergence from routines is associated with in-depth cognitive processing (Gist \& Mitchell, 1992) that can further enhance scanning's effect on CEO self-efficacy through more powerful and useful vicarious and enactive mastery experiences. 
Furthermore, while scanning overall has a possible uncertainty-reducing effect (Aguilar, 1967), if combined with equally proactive scanning it can, in addition, provide anticipatory information that reduces unfavorable stress when a challenging situation is eventually encountered (Inzana et al., 1996). Proactive and intense scanning also reduces the potential distress reactions to unfavorable information, as these negative experiences are encountered ahead of time and are thus less threatening (Lazarus \& Folkman, 1984). In contrast, intense scanning in reaction to an event (that is, low proactiveness) exposes the individual to information that they have little ability to respond to in a timely manner, or to properly process. This increases the likelihood that this information will result in adverse reactions for the CEO, reducing their selfefficacy as described above (Bandura, 1982). As before, scanning that is more proactive than intense is unlikely to reach the thresholds necessary to provide much of a benefit. In sum, we expect that:

Hypothesis 2 (H2): SME CEOs that scan in a highly intense and proactive manner will demonstrate higher levels of self-efficacy compared to CEOs whose levels of scanning are low in intensity and proactiveness.

Hypothesis 3 (H3): SME CEOs that exhibit mismatched levels of intensity and proactiveness in their scanning (either more proactive than intense or more intense than proactive) will exhibit lower levels of self-efficacy compared to CEOs that scan with matched levels of intensity and proactiveness.

\section{SME CEO self-efficacy and firm innovation and performance}

Individual self-efficacy has previously been found to be associated with individual job performance (Judge et al., 2007). Further, despite initial findings (Hmieleski \& Baron, 2008b; Hmieleski \& Corbett, 2008), the associations of CEOs' self-efficacy with SME performance - and especially innovation - have not been well established. However, we believe that these links are likely to be present and significant given the influence that such individuals have on firm strategic actions and outcomes (Baum \& Bird, 2010; Hmieleski \& Baron, 2008a, 2008b). These 
individuals have high discretion and control over firm actions, and their decisions can strongly impact organizational outcomes; their self-efficacy thus becomes an important mediating process to consider (for example, Audia et al., 2000).

In general, self-efficacy beliefs have a direct impact in the behavioral responses of individuals as well as in the effort and persistence that the individual is likely to put into such behaviors (Bandura, 1997; Cardon \& Kirk, 2013; Stajkovic \& Luthans, 1998). Such an effect occurs through two processes. First, in what has been discussed as the situational appraisal phase (Karademas, Kafetsios, \& Sideris, 2007), high self-efficacy individuals perceive their context as less threatening and more positive. Second, when appraising their capabilities to successfully deal with situational demands, high self-efficacy individuals perceive higher levels of instrumentality and potential success (Lazarus \& Folkman, 1984).

Put differently, low levels of self-efficacy signal to individuals that the situation is both threatening and outside of their control (Litt, 1988); this indicates that their behaviors are not likely to be effective. Thus, low self-efficacy beliefs debilitate the capabilities of individuals to act (Stajkovic \& Luthans, 1998). In the case of SME CEOs, this can relate to stagnation and inertia. Contrarily, high self-efficacy SME CEOs are more likely to look for opportunities presented by a situation (Hisrich \& Brush, 1986) and to manifest and sustain effective strategic choices that can translate into greater levels of firm innovation and performance, due to higher potential performance expectancies that self-efficacy is associated with (Schwoerer, May, Hollensbe, \& Mencl, 2005). They are also less likely to be affected by fear of uncertainty and less likely to be resistant to change, which enables them to function effectively in situations that others would be hesitant to approach (Wood \& Bandura, 1989).

The overall relationship between a CEO's scanning, self-efficacy, and firm level outcomes also draws conceptual support from the theory of planned behavior (Ajzen, 1985; Ajzen, 1991) with its original moorings in the theory of reasoned action (Fishbein \& Ajzen, 1975). At their core, the two theoretical frameworks offer an information-processing perspective on how external stimuli influence a person's intentions and proclivities to engage in behaviors by affecting their belief structures about those behaviors (Doll \& Ajzen, 1992). Ajzen (1991) suggests that control beliefs give rise to perceptions of self-efficacy in an individual and these beliefs are affected by an individual's past experiences with the behavior and secondhand information that the person receives from 
experiences of others. The better is the amount and quality of such information, the lesser is the degree of impediments that an individual perceives about their ability to carry out that behavior, thereby enhancing self-efficacy. The upshot of these arguments that is relevant for our study is that scanning serves as a key driver for CEO self-efficacy and, through it, the eventual strategic behaviors that lead to meaningful performance outcomes for SMEs. ${ }^{2}$

In sum, high CEO self-efficacy is likely to help manifest the behavioral responses that facilitate pursuing novel opportunities and capabilities, thus enhancing the SME innovation-related outcomes while competing in a declining industry. This is so because CEOs with such beliefs are more likely to perceive the change associated with industry decline as a situation with positive potential as well as seeing themselves as capable stewards that can deal with the demands of this change. They are also likely to manifest high levels of persistence and focus in their work that will further lead to high levels of job, and ultimately firm, innovation and performance. We therefore propose that SME CEO self-efficacy will mediate the effects of scanning intensity and proactiveness on firm innovation and performance.

Hypothesis 4: SME CEO self-efficacy will mediate the effects of proactive and intense scanning on ( $\mathrm{H} 4 \mathrm{a}$ ) firm innovation and (H4b) firm performance.

\section{Methodology}

\section{Data and sampling procedure}

To test the hypotheses articulated above, we obtained unique firsthand data from SME CEOs in the US foundry industry. Specifically, in 2006, baseline surveys were sent to 583 foundries in six northeastern and mid-Atlantic states. A total of 173 foundries responded, including 40 foundries that provided multiple completed surveys from multiple executives. The 173 foundries represented a response rate of 30.1 percent; a response rate consistent with other surveys (Kaplowitz, Hadlock, \& Levine, 2004) and surveys sent to SME strategic leaders (Bartholomew 
\& Smith, 2006). In total, 230 individual foundry executives participated in the first phase of the study. However, given our focus, we only utilized surveys that were responded to by the 173 foundry CEOs.

To capture the influence of CEO scanning behaviors and self-efficacy on firm performance and innovation outcomes, a second wave of surveys were sent out in 2010 to collect information about firm innovativeness and performance. Because of regular attrition rates involved with multisurvey research designs, the challenges associated with studying CEOs in general, and standard missing data issues, our final sample consisted of 87 CEOs and firms for which complete data were available for at least some outcomes. It is important to note that this sample size is consistent with previous studies that have focused on comparably difficult to observe sociocognitive CEO attributes and behaviors (e.g., Miller, 1991; Peterson, Smith, Martorana, \& Owens, 2003). Further, we took a number of steps to address possible concerns over missing data, such using full information maximum likelihood (FIML) estimations in our models (Enders, 2001; Enders \& Bandalos, 2001), so as to utilize all available information and to ensure that models run on the maximum available sample size, as well as endogeneity (which we expand on more comprehensively below).

Our research design presents two notable advantages for the present study. First, the foundry industry is one that is posing noticeable constraints and challenges on incumbent firms, a context ripe for studying how our CEOs make a difference to their firms' fortunes. Second, the nature of this industry, and the requirements it imposes on firms in order for them to remain competitive, highlights the potential importance of CEO scanning activities and self-efficacy as mechanisms enabling these firms to innovate and renew themselves as their industry declines.

\section{Measures}

Due to the industry-specific nature of our study, we adopted a twopronged approach to develop our measures. While duly consulting extant scales in the literature, we attempted to ensure that the scales were relevant to our survey respondents. Given that our primary target group was CEOs of foundry companies, we were also mindful of maintaining parsimony in our measurement approach, to maximize participation and response rates. Specifically, we pretested our survey with 13 senior executives from the foundry industry. 


\section{CEO scanning intensity}

To measure CEO scanning intensity, we employed a scanning intensity scale based on the approach suggested by Aguilar (1967) and Hambrick (1982) (see also Beal, 2000). Based on our engagement with foundry executives and industry experts, we established that CEOs in this industry tend to emphasize three strategic domains: customers and competitors, operating cost management, and shop floor technology. To develop the scanning intensity scale, we asked CEOs on how frequently they sought information in each of the six areas pertaining to the three strategic domains: competitors, current customers, prospective customers, shopfloor technology, operating costs, and quality control. Using a 5-point Likert scale ( 1 = Once a year; 5 = Daily), scanning intensity was a composite index developed by averaging the intensity of scanning behaviors across the six areas $(\alpha=0.82)$.

\section{CEO scanning proactiveness}

In our interviews with foundry CEOs and industry experts, we found that scanning proactiveness manifested in the form of specific types of behaviors that CEOs engage in. For instance, when attempting to understand competitors, we found that a form of proactive scanning was an "espionage" mode of information gathering about competitor activities. Some foundry CEOs expressed their constant efforts to keep tabs on the relationship between the competitors and their customers - in the hope that the first sign of trouble would mean an opportunity for them to win a job contract. Similarly, in the area of shop-floor technology, proactive scanning took the form of attending foundry technology trade shows and spending significant efforts in gaining new insights with key technical personnel of equipment suppliers. Finally, in the area of operation cost management, two types of proactive scanning were prevalent: one where a CEO personally analyzed operating costs (and not just depended on cost accounting reports); and, second, where a CEO compared cost data with those of competitors. This form of scanning - that is, the proactive form - is much harder to perform because it is not easy to discern costs of competitor foundries without having a rich understanding of their internal operations, which needs intrusive efforts on the part of a focal CEO to find such information. We isolated these behavioral tendencies to develop a group of items that reflect proactive and 
intrusive scanning behavior in the areas of competitor scanning, customers, shop-floor technology, and cost management; in contrast to the frequency approach used in measuring scanning intensity, here we focused more closely on specific types of scanning behaviors. It is important to note that scanning intensity and scanning proactiveness are related, but distinct, facets of CEO scanning efforts. Although both of these facets refer to behavioral efforts on the part of CEOs to obtain information, the former pertains solely to the amount of information sought across domains whereas the latter reflects how that information is collected, particularly in terms of the persistence with which CEOs go about obtaining the information in intrusive ways.

Based on these specific behavioral patterns discerned through our firsthand observations of foundry CEOs and through interviews with them, we developed the scale to measure scanning proactiveness based on seven distinct activities, with items worded as, "I" ... (a) try to attend most major trade shows on foundry technology; (b) spend time with suppliers to understand technological trends; (c) discuss market trends and new market opportunities with top executives in other foundries and/or (d) visit competitor foundries; spend time at customers' premises; (e) gather information about competitors' customers; (f) spend time analyzing my foundry's production costs; and (g) personally compare my foundry's costs with other foundries. We asked our respondents to rate the degree to which they engaged in each of these types of activities, using a 7-point Likert scale, (1 = Very rarely; 7 = Very frequently), which was then computed as a composite index of scanning proactiveness by averaging the extent of proactiveness in scanning behaviors across the seven activities $(\alpha=0.78)$.

\section{CEO self-efficacy}

We developed our measure of CEO self-efficacy based on existing approaches (Baum \& Bird, 2010; Chen et al., 1998) as well as considerations of relevance to the industry context of the study (for example, $\mathrm{Au}$ dia et al., 2000). Our engagement with industry executives consistently revealed three primary skill domains that were of critical importance to CEOs in the foundry industry; namely, shop floor technology, cost management, and sales and marketing. We measured CEO self-efficacy by asking respondents to rate whether they were confident of their skills 
in each of the three domains and to what extent they believed that their skills in each were better than their counterparts. These questions utilized a 5-point Likert scale (1 = Strongly disagree; 5 = Strongly agree) $(\alpha=0.70)$.

\section{Firm performance}

Because all of the firms in our sample were privately owned SMEs, we could not use market- or accounting-based measures of performance such as return-on assets, market-to-book value, or stock price. Furthermore, there is strong evidence that market-based measures of performance do not necessarily capture the performance of new ventures or SMEs adequately (Shepherd \& Wiklund, 2009). Instead, consistent with prior work (for example, Hmieleski \& Baron, 2008a, 2008b; Hmieleski \& Corbett, 2008), we retrieved sales data for 2006 and 2010 from the Dun and Bradstreet Million Dollar Database. As a result, data were gathered on firm revenues, which are considered as a dominant indicator of firm performance in the foundry industry. Consistent with recent recommendations (Certo, Busenbark, LePine, \& Kalm, in press; Wiseman, 2009), we used the unscaled measure of firm revenues in our models.

\section{Firm innovation}

We developed the scales for measuring innovation outcomes based on the well-established and validated scales used by Subramaniam and Youndt (2005), which are anchored in prior seminal work (Henderson \& Clark, 1990; Tushman \& Anderson, 1986). Again, our careful consultations with industry insiders were instrumental in allowing us to modify the language of the scale items to enhance their representativeness and relevance to the US foundry industry. In particular, we changed "innovations" to "improvements" in all items and replaced "product/service" to more specific and industry-relevant terms like "production yield," "cost of castings," and "new technology." Consistent with Subramaniam and Youndt, both items utilized a 7-point Likert scale where the responses were offered relative to the competition ( 1 = Weaker than competition; $4=$ Similar to competition; $7=$ Stronger than competition). Incremental innovation was measured with a 3-itemscale assessing the firm's overall capability to reinforce and extend its current expertise in terms of 
production yield, cost of castings, and market share $(\alpha=0.69)$. Radical innovation was also measured with a 3-item scale assessing the firm's capability to initiate a clear and frame-breaking shift from its current way of doing things in terms of entering new markets, embracing new technologies, and taking on radically new casting jobs $(\alpha=0.84)$.

\section{Control variables}

To account for possible confounding factors, we controlled for an array of relevant CEO- and firm-level attributes. To account for CEO-level factors, we controlled for CEO age, industry experience, and tenure with the focal firm. We also controlled for functional breadth as a proxy for CEO control or power. In case there were measurement effects due to our survey format, we controlled for paper-based or online survey. To account for firm-level inertia effects, we controlled for the age of the firm, and baseline levels of performance, incremental innovation, and radical innovation (that is, "Baseline Outcome at T1" for each outcome of interest).

\section{Analyses}

Data were analyzed with a series of ordinary least squares (OLS) regression models that included testing the main effects of scanning intensity on self-efficacy (H1; Model 2), and the effects of congruence between scanning intensity and proactiveness at different levels of scanning ( $\mathrm{H} 2$ and H3; Model 3). For the latter, we utilized a polynomial approach (Edwards, 2002) in which self-efficacy was regressed on scanning intensity and scanning proactiveness, their product term, and their respective squared terms as follows:

$$
S E=\beta_{0}+\beta_{1} S I+\beta_{2} S P+\beta_{3} S I^{2}+\beta_{4}\left(S I^{*} S P\right)+\beta_{5} S P^{2}+e
$$

where SE is self-efficacy, SI is scanning intensity, and SP is scanning proactiveness. Information from these equations was then utilized to test the slope of the congruence line (representing a comparison between low and high levels of scanning when proactiveness and intensity are equal) and the curve of the incongruence line (representing a comparison between congruent and incongruent levels of scanning intensity 
and proactiveness). A positive congruence slope indicates support for $\mathrm{H} 2$, whereas a negative incongruence curve represents support for $\mathrm{H} 3$ (in that it demonstrates that congruent levels of proactiveness and intensity are associated with higher self-efficacy compared to excessive levels of proactiveness relative to intensity or excessive levels of intensity relative to proactiveness).

To test the indirect effects of scanning on firm innovation and performance, we employed a block variable approach (Edwards \& Cable, 2009). We collected polynomial regression estimates from a path model in which the scanning variables predicted the self-efficacy and all outcome variables (and accounting for the path between self-efficacy and all outcomes). We used these estimates to calculate weighted linear composites (that is, the block variables; Igra, 1979) that represented the effects of the scanning variables on the mediator and outcomes. We then used these weighted linear composites as replacements for the predictors of the scanning variables, creating an overall estimate of the path from scanning to the self-efficacy (that is, the alpha path) which, when combined with estimates of the paths from self-efficacy to the outcomes (that is, the beta paths), allows for an estimation of point estimates and confidence intervals for the hypothesized indirect effects.

\section{Results}

Table 2 presents means, standard deviations, and correlations among the variables included in our study. Table 3 presents the regression results of the models specified to predict self-efficacy from scanning intensity and scanning proactiveness. Notably, aside from the correlations between our focal dependent variables and their lagged controls (which is to be expected), the relatively low correlations between the variables suggest that biased estimates due to multicollinearity are not a concern. Nevertheless, we examine multicollinearity more closely in our supplemental analyses and robustness section below.

$\mathrm{H} 1$ predicted that SME CEO scanning intensity would be positively associated with self-efficacy. As can be seen from Table 3, Model 2, this was indeed the case $(\beta=.15, p<.01)$. H1 was thus supported.

$\mathrm{H} 2$ predicted that for CEOs whose scanning intensity is congruent with their scanning proactiveness, higher (as opposed to lower levels) of scanning would be associated with higher levels of self-efficacy. As can 


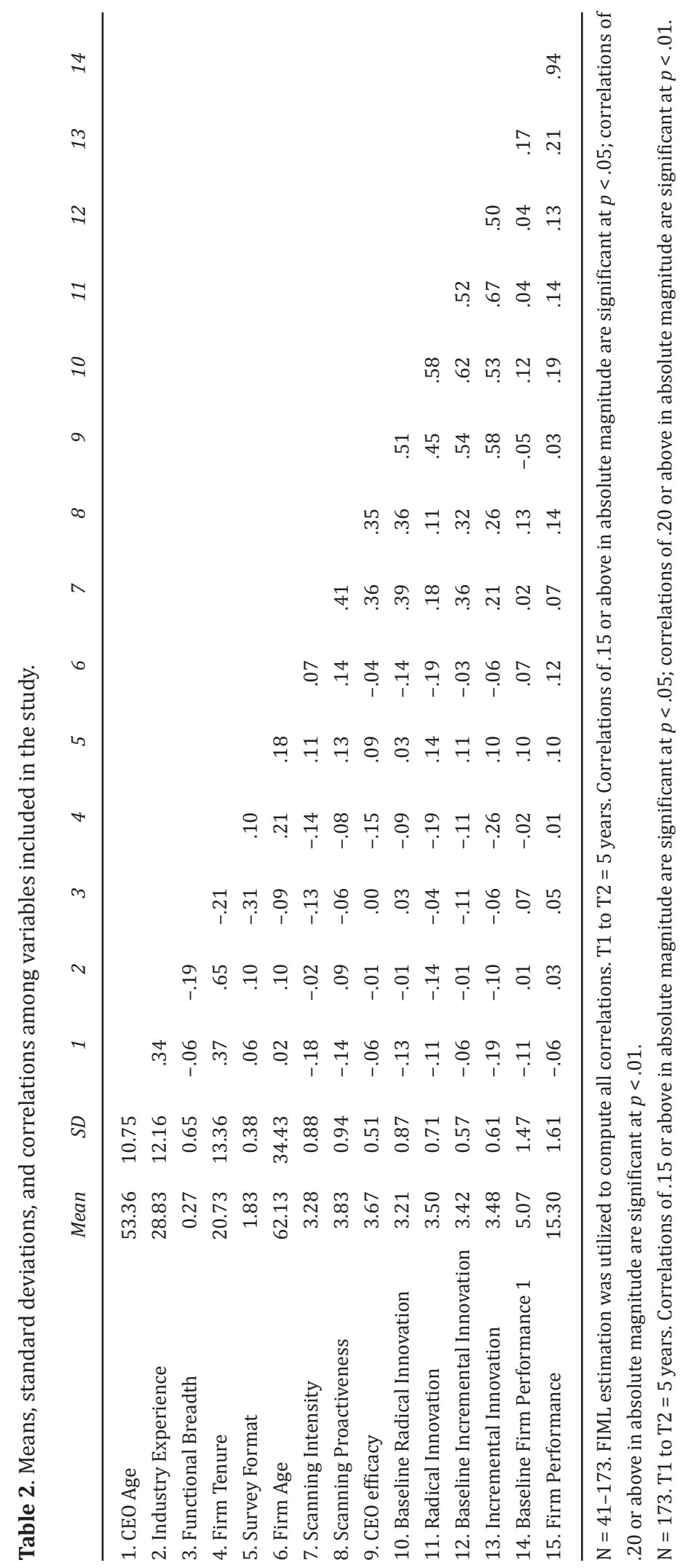


Table 3. Scanning proactiveness and intensity predicting CEO self-efficacy.

\begin{tabular}{|c|c|c|c|c|c|c|}
\hline & \multicolumn{2}{|c|}{ Model 1} & \multicolumn{2}{|c|}{ Model 2} & \multicolumn{2}{|c|}{ Model 3} \\
\hline & $b$ & t-value & $b \quad t-$ & t-value & $b$ & t-value \\
\hline \multicolumn{7}{|l|}{ Controls } \\
\hline CEO age & .00 & -.50 & .00 & .35 & .00 & .70 \\
\hline Industry experience & .01 & 1.39 & .00 & .48 & .00 & .66 \\
\hline Functional breadth & $-.01^{\dagger}$ & -1.95 & .00 & -1.01 & .00 & -.94 \\
\hline Firm tenure & -.01 & -.25 & .02 & .35 & .04 & .69 \\
\hline Survey format & .09 & .81 & .04 & .35 & .07 & .68 \\
\hline Firm age & .00 & -.20 & .00 & -.92 & .00 & -1.07 \\
\hline \multicolumn{7}{|l|}{ Independent variables } \\
\hline Scanning intensity (I) & & & $.15^{* *}$ & k 3.37 & $.16^{* *}$ & 3.45 \\
\hline Scanning proactiveness $(\mathrm{P})$ & & & $.11^{* *}$ & 2.77 & $.10^{*}$ & 2.62 \\
\hline Scanning intensity squared $\left(\mathrm{I}^{2}\right)$ & & & & & $-.10 \dagger-$ & -1.95 \\
\hline Scanning intensity $*$ Proactiveness (IxP) & & & & & $.09 \dagger$ & 1.67 \\
\hline Scanning proactiveness squared $\left(\mathrm{P}^{2}\right)$ & & & & & $-.06^{\dagger}$ & -1.69 \\
\hline Surface response characteristics & & & & & Estimate & t-value \\
\hline Fit slope $(I+P)$ & & & & & $.26^{* *}$ & 5.41 \\
\hline Misfit slope (I - P) & & & & & .06 & .85 \\
\hline Fit curve $\left(\mathrm{I}^{2}+\mathrm{IxP}+\mathrm{P}^{2}\right)$ & & & & & -.07 & -1.51 \\
\hline Misfit curve $\left(\mathrm{I}^{2}-\mathrm{IxP}+\mathrm{P}^{2}\right)$ & $-.25^{*}$ & -2.31 & & & & \\
\hline
\end{tabular}

$\mathrm{N}=164$ utilizing FIML; ${ }^{\dagger} \mathrm{p}<0.10,{ }^{*} \mathrm{p}<0.05,{ }^{* *} \mathrm{p}<0.01$.

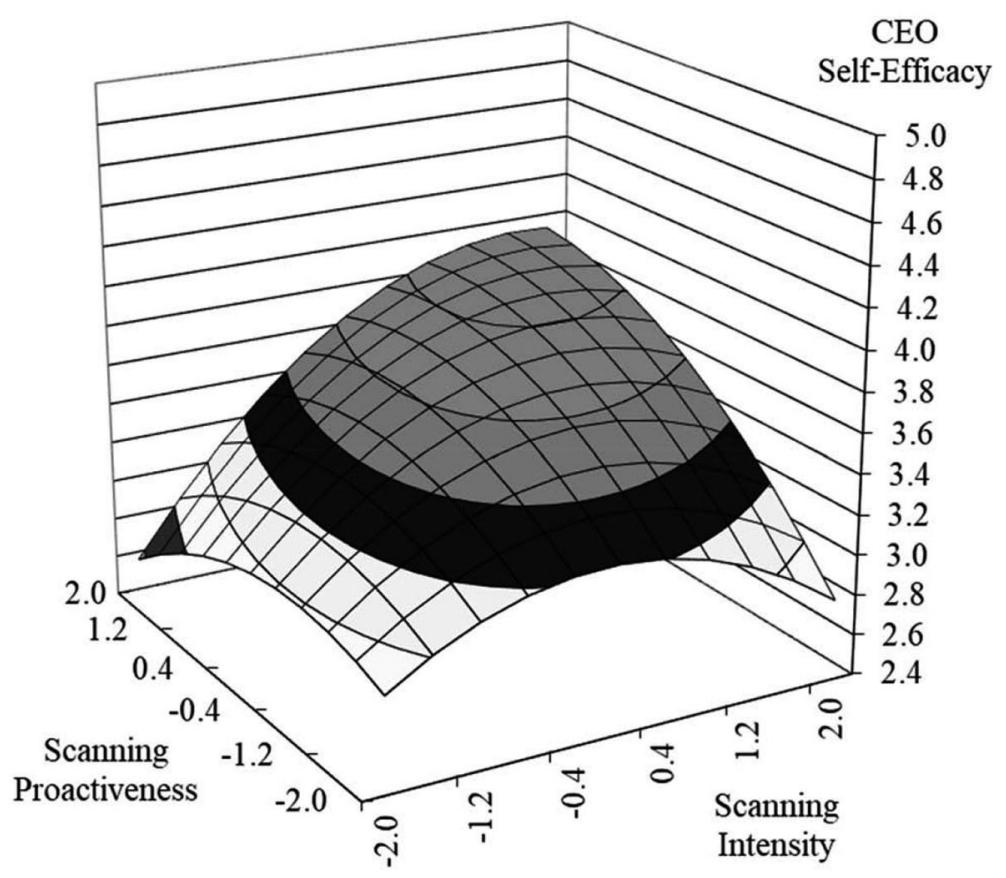

Figure 2. Interaction of scanning proactiveness and intensity in predicting CEO self-efficacy. 
be seen from the congruence slope derived from Model 3 estimates, this line is positive and significant $(\beta=.26, p<.01)$ indicating that this is indeed the case. $\mathrm{H} 2$ was thus supported.

H3 predicted that congruence between SME CEO scanning intensity and proactiveness would be associated with higher levels of self-efficacy (compared to intensity in excess of proactiveness, or proactiveness in excess of intensity). This hypothesis was tested by the incongruence curve derived from Model 3 estimates. This estimate is negative and significant $(\beta=-.25, p<.05)$, indicating that congruence between intensity and proactiveness is indeed associated with higher self-efficacy compared to incongruence between the same. H3 was thus supported. Figure 2 presents a graphical representation of these effects.

Table 4 presents the regression results for the indirect effects of the scanning variables through self-efficacy on firm performance ( $\mathrm{H} 4 \mathrm{a})$ and innovation (H4b). Overall, the block comprising the effects of the scanning variables was significant $(\beta=.46, p<.01)$. As discussed before, this estimate represents the alpha path for testing the hypothesized indirect effects. Furthermore, self-efficacy was found to positively predict radical innovation $(\beta=.12, p<.05)$. The overall indirect effect was significant (IE

Table 4. Mediating effects of CEO self-efficacy on firm performance and innovation.

\begin{tabular}{|c|c|c|c|c|c|c|c|c|}
\hline & \multicolumn{2}{|c|}{$\begin{array}{c}\text { CEO } \\
\text { self-efficacy }\end{array}$} & \multicolumn{2}{|c|}{$\begin{array}{l}\text { Radical } \\
\text { innovation }\end{array}$} & \multicolumn{2}{|c|}{$\begin{array}{l}\text { Incremental } \\
\text { innovation }\end{array}$} & \multicolumn{2}{|c|}{$\begin{array}{c}\text { Firm } \\
\text { performance }\end{array}$} \\
\hline & $\beta$ & t-value & $\beta$ & t-value & $\beta$ & t-value & $\beta$ & t-value \\
\hline \multicolumn{9}{|l|}{ Controls } \\
\hline CEO age & .05 & .04 & .98 & .65 & .82 & .29 & .05 & .11 \\
\hline Industry experience & .05 & .47 & -.11 & -1.30 & .12 & .59 & .00 & .05 \\
\hline Functional breadth & .02 & .27 & -.03 & -.40 & -.07 & -.62 & .01 & .26 \\
\hline Firm tenure & -.06 & -.61 & .02 & .22 & -.17 & -.88 & .00 & .08 \\
\hline Survey format & .05 & .53 & .04 & .52 & -.05 & -.36 & .00 & .10 \\
\hline Firm age & $-.14^{\dagger}$ & -1.76 & -.04 & -1.07 & .02 & .22 & $.05^{\dagger}$ & 1.89 \\
\hline Baseline outcome at $\mathrm{T} 1$ & & & .04 & .72 & .15 & 1.00 & $.95^{* *}$ & 33.23 \\
\hline \multicolumn{9}{|l|}{ Independent variables } \\
\hline Scanning variables block & $.46^{* *}$ & 4.96 & $.11^{* *}$ & 3.00 & .11 & 1.32 & $.09^{* *}$ & 3.18 \\
\hline CEO efficacy & & & $.12^{*}$ & 2.69 & $.21^{\dagger}$ & 1.90 & $.08^{*}$ & 2.34 \\
\hline \multicolumn{9}{|l|}{ Indirect effects } \\
\hline Point estimate & & & $.50 *$ & 2.44 & $.40^{\dagger}$ & 1.77 & $.24^{*}$ & 2.14 \\
\hline 95\% Confidence interval ( & (LL UL) & & $(.10$ & $.91)$ & $(-.04$ & $.85)$ & $(.02$ & $.46)$ \\
\hline
\end{tabular}

$\mathrm{N}=127$ utilizing FIML. LL and UL respectively refer to the lower and upper $2.5 \%$ bounds of the $95 \%$ confidence interval for indirect effects. Performance is the log of sales in millions of dollars. ${ }^{\dagger} p<0.10 ;{ }^{*} p<0.05 ;{ }^{* *} p<0.01$ 
$=.50, p<.01$ ). In addition, the confidence interval for the indirect effect of the scanning variables to radical innovation through self-efficacy did not include zero $\left(\mathrm{CI}_{95 \%}=.10, .91\right)$. In terms of incremental innovation, the effect of self-efficacy was not as significant $(\beta=.21, p<.10$; IE $=.40, p<$ .10). The confidence interval for the indirect effect of the scanning variables to incremental innovation through self-efficacy did include zero $\left(\mathrm{CI}_{95 \%}=-.04, .85\right)$, thus indicating that this indirect effect did not hold for incremental innovation. H4a was thus supported for radical innovation, but not supported for incremental innovation.

In terms of firm performance, self-efficacy was positively associated with this outcome $(\beta=.08, p<.05)$. The overall indirect effect was significant (IE $=.24, p<.05$ ), and the confidence interval for the indirect effect of the scanning variables to radical innovation through self-efficacy did not include zero $\left(\mathrm{CI}_{95 \%}=.02, .46\right)$. $\mathrm{H} 4 \mathrm{~b}$ was thus supported.

\section{Supplemental analyses and robustness}

Given the nature of our data, we recognize that our models could be influenced by endogeneity in the forms of sample-induced and omitted variable biases. To examine whether this was an issue, we undertook a number of additional steps. First, we conducted an extensive online search of all 173 foundries that comprised our initial sample. ${ }^{3}$ Through this search, we conservatively identified only 20 foundries that showed evidence of having failed prior to 2010 .

Second, while the vast majority of foundries in our sample had not outright failed, there is the possibility that foundries with CEOs

3 We first searched to see whether the given foundry was still currently in operation. In the majority of cases it was; thus, indicating that they had not failed or been acquired prior to 2010 . Foundries were deemed to be still currently operating if they exhibited clear signs of being operational such as having an up-to-date website, up-to -date business hours on Google reviews, and recent Google or Facebook reviews received from customers or other key stakeholders. In the majority of cases, foundries that were still in operation presented multiple - if not all - indicators listed above. In cases where clear signs of being operational were absent or questionable, we looked for archival documents that would offer some indication that the foundry had failed or been acquired prior to 2010 (for example, local newspapers or press releases), or was clearly still operational post-2010. According to these archival records, 11 foundries were found to have failed or been acquired prior to 2010 (including one during 2010). In cases where there was no clear evidence of having maintained operations or evidence of a failure, we attempted to contact the foundry directly via telephone. Nine foundries we attempted to contact directly had numbers that were no longer in service. For considerations of being conservative, we assumed that these foundries had failed prior to 2010 even though they may have failed afterward. 
exhibiting systemically low levels of scanning intensity, proactiveness, or self-efficacy dropped out of our sample due to nonresponse or failure. As an initial step to rule out sample-induced endogeneity, we compared the means of CEOs' scanning proactiveness, intensity, and self-efficacy between the group of firms that dropped out of the sample and those that remained in the sample. These $t$-tests revealed no significant differences between CEOs in either group of firms (that is, those that remained in our sample and those that dropped out) on all three key attributes. To further rule out sample-induced endogeneity, we followed the steps suggested by Certo, Busenbark, Woo, and Semadeni (2016) and used an instrumental variable - the primary type of metal the foundry specialized in - that was significantly correlated with the likelihood of being in our final sample (that is, not dropping out due to failure or nonresponse), but was not significantly correlated with our innovation or performance outcomes (Wooldridge, 2009). We then ran the first stage of a Heckman model using this instrument and the other variables used in our model to predict whether a firm was likely to remain in our sample. In this first-stage model, none of our focal independent or mediator variables were significant predictors. Certo and colleagues note that if the independent variable "is not significant in the first stage of a Heckman model ... selection bias will not exist" (2016, p. 17).

To rule out a potential omitted variable bias, we also ran a two-stage least-squares model (that is, 2SLS; see Antonakis, Bendahan, Jacquart, \& Lalive, 2010; Certo et al., 2016). In these models, the mediator was regressed on the block variable representing the scanning variables, the outcome variables regressed on the mediator, and the mediator and outcomes allowed to covary. Results indicated that only the effects of selfefficacy on incremental innovation were not significant $(\beta=.63, p>.10)$, just as it was in our main analyses. All other results were unchanged in terms of coefficient sign, magnitude, or significance. Overall, the results of these supplemental analyses suggest that endogeneity - due to sample selection or omitted variable biases - was not a significant concern for our study.

Finally, we tested for multicollinearity by obtaining the variance inflation factors (VIFs) for all models. No VIFs in any of the models were above 10 , and the mean VIFs were never above 5 (mean VIF $=1.52$ ). We are thus confident that multicollinearity was also not an issue. 


\section{Discussion}

Understanding the drivers of SME innovation and growth while competing in declining industries has been an increasingly important area of research (for example, Bumgardner et al., 2011; Chandler et al., 2014). In this study, we have built on this line of inquiry by examining key CEO scanning activities and focused on the important role that different aspects of scanning - scanning intensity and scanning proactiveness - play in fostering self-efficacy in CEOs and subsequent firm innovation and performance for SMEs competing in a declining industry. In doing so, we found that scanning intensity is positively associated with self-efficacy and that this relationship is further augmented when the interactive effect of scanning proactiveness is accounted for. In addition, we found support for a mediated relationship in which CEO self-efficacy mediates the influence of scanning intensity on SME performance and innovation, contingent on scanning proactiveness. As a corollary, the intermediary role of CEO self-efficacy, which we discuss next, also provides a plausible pathway through which future research can explore when and how SME strategic leaders affect the processes by which knowledge is managed in their firms.

\section{Contributions to theory}

To the best of our knowledge, our study is among the first to examine the distinctive influence that those individuals in strategic leadership position in SMEs can have in navigating industry decline (for a possible exception, see Beal, 2000). Our theory and findings suggest that scanning behaviors may allow those in SME strategic leadership positions to identify opportunities that emerge as industries decline and support their self-efficacy in such a way as to pursue these opportunities in a manner that stimulates innovation and growth.

More generally, we identified important behaviors - scanning intensity and proactiveness - that SME strategic leaders, and possibly even entrepreneurs, may undertake to increase their self-efficacy. Although research on self-efficacy in entrepreneurship and the small business context has revealed several important insights, it has generally overlooked how SME strategic leaders may engage in social learning activities, and which types of activities they may engage in. 
Understanding the behavioral antecedents that influence self-efficacy in such scenarios is a key advancement in that such behavioral antecedents may challenge some of the boundary conditions held regarding the influence of self-efficacy over SME performance (e.g., Hmieleski \& Baron, 2008b). It is possible for instance, that scanning may have a dampening effect on the role of environmental dynamism because such scanning enables the collection of richer information from the environment. Interestingly, Lumpkin and Dess (2001) in a large-scale field study across several industries found that the proactiveness dimension of entrepreneurial orientation was more appropriate for growth-stage industries. Our study balances this view by exploring the critical importance of scanning, particularly the combinatorial effect of scanning intensity and proactiveness in driving innovation and growth in industries facing decline.

Our results also extend work on the antecedents of self-efficacy by demonstrating how information-gathering activities can help enhance individual self-efficacy, and that the way in which individuals engage in self-efficacy building activities can be as important as the activities themselves, providing a more detailed view of these processes.

Our focus on CEO self-efficacy in the SME context can also inform the works of entrepreneurship scholars who have developed a nuanced derivative of the self-efficacy construct - entrepreneurial self-efficacy - to sharpen its explanatory power as a consequential attribute, within the context of entrepreneurship, reflecting the unique constraints and requirements associated with being an entrepreneur (for example, limited resources, time pressure, and necessity of performing multiple essential functions). Although SME CEOs may not always identify as entrepreneurs or be considered entrepreneurs according to prevailing definitions (for example, Busenitz \& Barney, 1997; Chen et al., 1998; Wasserman, 2003), our study's findings are in line with prior work on entrepreneurial self-efficacy (for example, Baum \& Bird, 2010; Baum \& Locke, 2004; Zhao, Seibert, \& Hills, 2005). In influencing what strategy to pursue and how to implement it, behavioral choices of SME CEOs and their relation to self-efficacy can have large implications for innovation and performance, especially within a declining industry.

As a more broadly reaching contribution, having examined SME CEOs, our study extends the current state of understanding of strategic leadership and upper echelons theory. As Hambrick notes, we "have 
not studied the actual psychological and social processes that serve to transform executive characteristics into strategic action" (2007, p. 337). In this regard, our study addresses this issue by developing theory and empirically capturing some of the behaviors and actions that executives accomplish that translate toward strategic outcomes. Further, the idea that behavior can influence cognition has been largely underexplored in the upper echelons theory and the broader strategic management literature. The dominant view tends to accord importance to cognition as the driver of behavior (Hambrick \& Mason, 1984). Our study's findings highlight the plausibility of looking at the reverse causal mechanism as well and, in doing so, help identify pertinent managerial psychological processes that can influence organizational adaptation and innovation (Audia et al., 2000).

\section{Implications for practice}

Overall, the arguments and findings that we presented offer some important insights for SME strategic leaders. First, our study's arguments highlight the importance of SME strategic leaders being active "prospectors" of information in their firms' external environments rather than passive "receptors." Secondly, in examining two aspects of scanning, we have illustrated the importance for these individuals to not only scan their environments in a comprehensive fashion (that is, scanning intensity), but also to scan their environments with a focus on identifying how these may change in the future (that is, scanning proactiveness); this appears to be a key consideration for allowing firms to maintain their competitive position as industries decline. Moreover, our arguments and findings demonstrate that SME strategic leaders need not view scanning intensity and scanning proactiveness as two distinct activities that present trade-offs. Rather, scanning intensity and scanning proactiveness are very much orthogonal by nature, and engaging in both of these behaviors is possible; those individuals who demonstrate consistent levels of ambidexterity in engaging in both scanning intensity and scanning proactiveness do so at the benefit of their own abilities and their firms' innovativeness and performance.

We should note that our study's theory and findings also paint a positive picture for SME strategic leaders interested in solutions that allow them to counter the challenges of industry decline and that might enable 
them to increase their self-efficacy. In particular, our findings may prove particularly useful for those individuals who consider themselves to have relatively low self-efficacy, or who - for whatever reason - have suffered a crisis of confidence and are attempting to rebuild their self-efficacy. We have identified a set of key behaviors - scanning intensity and proactiveness - along with their underlying components that SME strategic leaders can engage in to enhance their self-efficacy. Therefore, we submit to these individuals that their success or that of the firm they are tasked with running is not necessarily bound by their current levels of self-efficacy; they can take actionable measures to improve their self-efficacy and thereby impact the innovativeness and performance of their firms.

To this point, our results present a generally positive view of self-efficacy in SME CEOs as it relates to firm innovativeness and performance. When considered alongside research that has examined related concepts such as locus of control and positive self-regard, this body of research seems to suggest that firms would - more often than not - have something to gain from executives who feel efficacious and empowered to accomplish their functions. For instance, this could be particularly relevant for SMEs with boards of directors that include venture capitalists (Garg, 2013; Garg \& Eisenhardt, in press). In certain instances, directors on SME boards could potentially serve stakeholders and other key investors well through empowering CEOs and other executives, rather than by simply monitoring them.

\section{Future research opportunities}

As a demonstration of the role of scanning and its influence on selfefficacy and SME performance while competing in a declining industry, our study provides several opportunities for future research. First, our empirical work was undertaken within the context of a single industry in decline, which may raise concerns regarding the generalizability of the research. Although this allowed us to control for potentially confounding effects at the industry level, there is a need to replicate our study across a wider array of industries. Relatedly, while our performance data is objective - still a relative rarity in entrepreneurship research - and comparable to that of previous studies that have focused on CEOs or executives within privately owned SMEs (Herrmann \& Nadkarni, 2014; Nadkarni \&Herrmann, 2010) and consistent with how executives in the foundry 
industry benchmark performance, accounting- and market-based measures of performance remain preferred indicators of performance. As such, future research may further consider assessing SME performance in a more comprehensive fashion (see Miller, Le Breton-Miller, Amore, Minichilli, \& Corbetta, 2017; Neville, Orser, Riding, \& Jung, 2014).

We also focused on CEOs as those individuals primarily and directly responsible for influencing firm innovation and performance. However, CEO self-efficacy can have other, indirect, effects through others' perception of the same. That is, a high self-efficacy CEO can become an inspiration and source of comfort and confidence for other members of the firm, leading to increased motivation and, in the aggregate, increased performance. Alternatively, a CEO low in self-efficacy can be a source of doubt for others in the firm, with opposite effects. Thus, an additional potentially interesting direction for future research would be to investigate whether leader-level learning processes, such as those associated with scanning behaviors, could translate into a learning organization (Slater \& Narver, 1995). Role modeling processes could lead to "trickle down" effects of these approaches (see Schaubroeck et al., 2012 for a similar discussion) thus providing a pathway through which leader behaviors translate into changing organizational climate, thus ultimately changing the organization.

Sample limitations notwithstanding, our study suggests that some promising directions for future research would lie in studying the sociocognitive traits of SME strategic leaders facing industry decline in a comprehensive manner. ${ }^{4}$ One possible approach could be to leverage set-theoretic methods (for example, qualitative comparative analysis, QCA) to develop theory on certain archetypes of SME strategic leaders that might be associated with superior firm performance and innovation in declining industries. Self-efficacy could also be leveraged to further explore the concept of narcissism and overconfidence in SME strategic leadership (for example, Engelen, Neumann, \& Schwens, 2015; Navis \& Ozbek, 2016). Additionally, recent theory provides several exemplars of firm founders and venture CEOs who have risen to celebrity prominence (for example, Bill Gates, Mark Zuckerberg, Jeff Bezos) and the "shackles" associated with such attained celebrity (Lovelace, Bundy, Hambrick, \& Pollock, 2018). We believe scanning (particularly an ideal combination

4 We thank our anonymous reviewer for pointing out these interesting avenues for future research. 
of intensity and proactiveness) and self-efficacy can be further leveraged to examine when and how such entrepreneurs and CEOs rapidly rise to attain celebrity status.

\section{Conclusion}

Our study provides an important theoretical and empirical demonstration of the role of scanning behaviors in the emergence of SME strategic leader self-efficacy as it relates to firm innovation and performance within a declining industry. As such, we hope that our study will stimulate further inquiries into the role and influence of strategic leaders of firms competing in declining industries, the behavioral antecedents of self-efficacy, and the role of strategic leader self-efficacy in affecting critical firm outcomes.

\section{References}

Aguilar, F. J. (1967). Scanning the business environment. New York, NY: Macmillan.

Ajzen, I. (1985). From intentions to actions: A theory of planned behavior. In Action control (pp. 11-39). Berlin, Heidelberg: Springer.

Ajzen, I. (1991). The theory of planned behavior. Organizational Behavior and Human Decision Processes, 50(2), 179-211. doi:10.1016/0749-5978(91)90020-T

Alavi, M., \& Leidner, D. E. (2001). Review: Knowledge management and knowledge management systems: Conceptual foundations and resaerch issues. MIS Quarterly, 25(1), 107-136.doi:10.2307/3250961

Almeida, P., Phene, A., \& Grant, R. (2003). Innovation and knowledge management: Scanning, sourcing, and integration. In Handbook of organizational learning and knowledge management (pp. 356-371).

Ansoff, H. I. (1975). Managing strategic surprise by response to weak signals. California Management Review, 18(2), 21-33. doi:10.2307/41164635

Antonakis, J., Bendahan, S., Jacquart, P., \& Lalive, R. (2010). On making causal claims: A review and recommendations. Leadership Quarterly, 21(6), 1086-1120. doi: 10.1016/j.leaqua.2010.10.010

Audia, P. G., Locke, E. A., \& Smith, K. G. (2000). The paradox of success: An archival and laboratory study of strategic persistence following radical environmental change. Academy of Management Journal, 43(5), 837-854.

Auster, E., \& Choo, C. W. (1994). CEOs, information, and decision making: Scanning the environment for strategic advantage. Library Trends, 43(2), 206-225.

Bandura, A. (1977). Social learning theory. Englewood Cliffs, NJ: Prentice Hall. 
Bandura, A. (1982). Self-efficacy mechanism in human agency. American Psychologist, 37(2), 122-147. doi:10.1037/0003-066X.37.2.122

Bandura, A. (1986). Social foundations of thought and action. Englewood Cliffs, NJ: Prentice Hall.

Bandura, A. (1997). Self-efficacy: The exercise of control. New York, NY: Freeman.

Barringer, B. R., \& Bluedorn, A. C. (1999). The relationship between corporate entrepreneurship and strategic management. Strategic Management Journal, 20(5), 421-444. doi:10.1002/(ISSN)1097-0266

Bartholomew, S., \& Smith, A. (2006). Improving survey response rates from chief executive officers in small firms: The importance of social networks. Entrepreneurhship Theory and Practice, 30(1), 83-96. doi:10.1111/j.1540-6520.2006. 00111.x

Bateman, T. S., \& Crant, J. M. (1993). The proactive component of organizational behavior: A measure and correlates. Journal of Organizational Behavior, 14(2), 103-118. doi:10.1002/ (ISSN)1099-1379

Baum, J. C., Li, S. X., \& Usher, J. M. (2000). Making the next move: How experiential and vicarious learning shape the locations of chains' acquisitions. Administrative Science Quarterly, 45(4), 766-801. doi:10.2307/2667019

Baum, J. R., \& Bird, B. J. (2010). The successful intelligence of high-growth entrepreneurs: Links to new venture growth. Organization Science, 21(2), 397412,587. doi:10.1287/orsc. 1090.0445

Baum, J. R., \& Locke, E. A. (2004). The relationship of entrepreneurial traits, skill, and motivation to subsequent venture growth. Journal of Applied Psychology, 89(4), 587-598. doi:10.1037/0021-9010.89.4.587

Beal, R. M. (2000). Competing effectively: Environmental scanning, competitive strategy, and organizational performance in small manufacturing firms. Journal of Small Business Management, 38(1), 27-47.

Becherer, R. C., \& Maurer, J. G. (1999). The proactive personality disposition and entrepreneurial behavior amon small company presidents. Journal of Small Business Management, 37(1), 28-36.

Biery, M.-E. 2016. The state of U.S. small business entering 2016. Forbes. Retrieved from https://www.forbes.com/sites/sageworks/2016/01/17/ the-state-of-u-s-small-businessesentering-2016/\#679c01a82f0b

Boyd, B. K., \& Fulk, J. (1996). Executive scanning and perceived uncertainty: Amultidimensional model. Journal of Management, 22(1), 1-21. doi:10.1177/014920639602200101

Boyd, N. G., \& Vozikis, G. S. (1994). The influence of self-efficacy on the development of entrepreneurial intentions and actions. Entrepreneurship Theory and Practice, 18(4), 63-77. doi:10.1177/104225879401800404

Bumgardner, M., Buehlmann, U., Schuler, A., \& Crissey, J. (2011). Competitive actions of small firms in a declining market. Journal of Small Business Management, 49(4), 578-598. doi:10.1111/j.1540-627X.2011. 00337.x

Busenitz, L. W., \& Barney, J. B. (1997). Differences between entrepreneurs and managers in large organizations: Biases and heurisitics in strategic 
decision-making. Journal of Business Venturing, 12(1), 9-30. doi:10.1016/ S0883-9026(96)00003-1

Cardon, M. S., \& Kirk, C. P. (2013). Entrepreneurial passion as a mediator of the selfefficacy to persistence relationship. Entrepreneurship Theory and Practice, 39(5), 1027-1050. doi:10.1111/etap.12089

Certo, S. T., Busenbark, J. R., LePine, J. A., \& Kalm, M. in press. Divided we fall: How ratios undermine strategic management research. Organizational Research Methods. Retrieved from https:// media.terry.uga.edu/socrates/publications/2018/2003/ Certo et al. forthcoming Ratios in strategic management. pdf? ga =2012.210563029.1744392570.1523128016-1730824694.1522869440

Certo, S. T., Busenbark, J. R., Woo, H.-S., \& Semadeni, M. (2016). Sample selection bias and Heckman models in strategic management resaerch. Strategic Management Journal, 37(13), 2639-2657. doi:10.1002/smj.2475

Cervone, D., \& Peake, P. K. (1986). Anchoring, efficacy, and action: The influence of judgmental heuristics on self-efficacy judgments and behavior. Journal of Personality and Social Psychology, 50(3), 492. doi:10.1037/0022-3514.50.3.492

Chandler, G. N., Broberg, J. C., \& Allison, T. H. (2014). Customer value propositions in declining industries: Differences between industry representative and highgrowth firms. Strategic Entrepreneurship Journal, 8(3), 234-253. doi:10.1002/sej. v8.3

Chandler, G. N., \& Hanks, S. H. (1994). Market attractiveness, resource-based capabilities, venture strategies and venture performance. Journal of Business Venturing, 9(4), 331-349. doi:10.1016/0883-9026(94)90011-6

Chen, C. C., Greene, P. G., \& Crick, A. (1998). Does entrepreneurial self-efficacy distinguish entrepreneurs from managers? Journal of Business Venturing, 13(4), 295-316. doi:10.1016/S0883-9026(97)00029-3

Choo, C. W. (2001). Environmental scanning as information seeking and organizational learning. Information Research, 7(1), 7-1.

Cooper, A. C., Folta, T. B., \& Woo, C. (1995). Entrepreneurial information search. Journal of Business Venturing, 10(2), 107-120. doi:10.1016/0883-9026(94)00022-M

Covin, J. G., \& Slevin, D. P. (1990). New venture strategic posture, structure, and performance: An industry life cycle analysis. Journal of Business Venturing, 5(2), 123-135. doi:10.1016/0883-9026(90)90004-D

Covin, J. G., \& Slevin, D. P. (1991). A conceptual model of entrepreneurship as firm behavior. Entrepreneurship Theory and Practice, 16(1), 7-26. doi:10.1177/104225879101600102

Cowan, D. A. (1986). Developing a process model of problem recognition. Academy of Management Review, 11(4), 763-776. doi:10.5465/amr.1986.4283930

Crant, J. M. (1996). The proactive personality scale as a predictor of entrepreneurial intentions. Journal of Small Business Management, 34(3), 42-49.

Crant, J. M. (2000). Proactive behavior in organizations. Journal of Management, 26(3), 435-462. doi:10.1177/014920630002600304 
Crant, J. M., \& Bateman, T. S. (2000). Charismatic leadership viewed from above: The impact of proactive personality. Journal of Organizational Behavior, 21(1), 63-75. doi:10.1002/(ISSN)1099-1379

Daft, R., \& Weick, K. (1984). Toward a model of organizations as interpretation systems. Academy of Management Review, 9(2), 286. doi:10.5465/ amr.1984.4277657

Daft, R. L., Sormunen, J., \& Parks, D. (1988). Chief executive scanning, environmental characteristics, and company performance: An empirical study. Strategic Management Journal, 9(2), 123-139. doi:10.1002/(ISSN)1097-0266

Danneels, E. (2008). Organizational antecedents of second-order competences. Strategic Management Journal, 29(5), 519-543. doi:10.1002/(ISSN)1097-0266

Doll, J., \& Ajzen, I. (1992). Accessibility and stability of predictors in the theory of planned behavior. Journal of Personality and Social Psychology, 63(5), 754. doi:10.1037/0022-3514.63.5.754

Dollinger, M. J. (1984). Environmental boundary spanning and information processing effects on organizational performance. Academy of Management Journal, 27(2), 351-368.

Doz, Y. L., \& Kosonen, M. (2010). Embedding strategic agility: A leadership agenda for accelerating busniess modeal renewal. Long Range Planning, 42(2/3), 370382. doi: 10.1016/j.lrp.2009.07.006

Earley, P. C. (1994). Self or group? Cultural effects of training on self-efficacy and performance. Administrative Science Quarterly, 39(1), 89-117. doi:10.2307/2393495

Earley, P. C., \& Erez, M. (1991). Time-dependency effects of goals and norms: The role of cognitive processing on motivational models. Journal of Applied Psychology, 76(5), 717-724. doi:10.1037/0021-9010.76.5.717

Edwards, J. R. (2002). Alternatives to difference scores: Polynomial regression analysis and response surface methodology. In F. Drasgow \& N. Schmitt (Eds.), Measuring and analyzing behavior in organizations: Advances in measurement and data analysis (pp. 350-400). San Francisco, CA: Jossey-Bass.

Edwards, J. R., \& Cable, D. (2009). The value of congruence. Journal of Applied Psychology, 94 (3), 654-677. doi:10.1037/a0014891

Elenkov, D. S. (1997). Strategic uncertainty and environmental scanning: The case for institutional influences on scanning behavior. Strategic Management Journal, 18(4), 287-302. doi:10.1002/(ISSN)1097-0266

Enders, C. K. (2001). The performance of the full information maximum likelihood estimator in multiple regression models with missing data. Educational and Psychological Measurement, 61(5), 713-740. doi:10.1177/0013164401615001

Enders, C. K., \& Bandalos, D. L. (2001). Te relative performance of full information maximum likelihood estimation for missing data in structural equation models. Structural Equation Modeling, 8(3), 430-457. doi:10.1207/ S15328007SEM0803_5

Engelen, A., Neumann, C., \& Schwens, C. (2015). “Of course I can”: The effect of CEO overconfidence on entrepreneurially oriented firms. Entrepreneurship Theory and Practice, 39(5), 1137-1160. doi:10.1111/etap.12099 
Etzioni, A. (1967). Mixed-scanning: A" third" approach to decision-making. Public Administration Review, 27(5), 385-392. doi:10.2307/973394

Etzioni, A. (1986). Mixed scanning revisited. Public Administration Review, 46(1), 8-14. doi:10.2307/975437

Felin, T., \& Hesterly, W. S. (2007). The knowledge-based view, nested heterogeneity, and new value creation: Philosophical considerations on the locus of knowledge. Academy of Management Review, 32(1), 195-218. doi:10.5465/ amr.2007.23464020

Fishbein, M., \& Ajzen, I. (1975). Belief, attitude, intention and behavior: An introduction to theory and research. Reading, MA: Addison-Wesley.

Garg, S. (2013). Venture boards: Distinctive monitoring and implications for firm performance. Academy of Management Review, 38(1), 90-108. doi:10.5465/ amr.2010.0193

Garg, S., \& Eisenhardt, K. M. (in press). Unpacking the CEO-board relationship: How strategy-making happens in entrepreneurial firms. Academy of Management Journal. doi:10.5465/amj.2014.0599

Garg, V. K., Walters, B. A., \& Priem, R. L. (2003). Chief executive scanning emphases, environmental dynamism, and manufacturing firm performance. Strategic Management Journal, 24(8), 725-744. doi:10.1002/(ISSN)1097-0266

Ghoshal, S. (1988). Environmental scanning in Korean firms: Organizational isomorphism in action. Journal of International Business Studies, 19(1), 69-86. doi:10.1057/palgrave.jibs.8490375

Gist, M. E., \& Mitchell, T. R. (1992). Self-efficacy: A theoretical analysis of its determinants and malleability. Academy of Management Review, 17(2), 183-211. doi:10.5465/amr.1992.4279530

Grant, A. M., \& Ashford, S. J. (2008). The dynamics of proactivity at work. Research in Organizational Behavior, 28, 3-34. doi:10.1016/j.riob.2008.04.002

Grant, R. M. (1996). Toward a knowledge-based theory of the firm. Strategic Management Journal, 17, 109-122. doi:10.1002/smj.4250171110

Hambrick, D. C. (1981). Environment, strategy, and power within top management teams. Administrative Science Quarterly, 26(2), 253-271. doi:10.2307/2392472

Hambrick, D. C. (1982). Environmental scanning and organizational strategy. Strategic Management Journal, 3(2), 159-174. doi:10.1002/(ISSN)1097-0266

Hambrick, D. C. (2007). Upper echelons theory: An update. Academy of Management Review, 32(2), 334-343. doi:10.5465/amr.2007.24345254

Hambrick, D. C., \& Mason, P. A. (1984). Upper echelons: The organization as a reflection of its top managers. Academy of Management Review, 9(2), 193-206. doi:10.5465/amr.1984.4277628

Helfat, C. E., \& Peteraf, M. A. (2015). Managerial cognitive capabilities and the microfoundations of dynamic capabilities. Strategic Management Journal, 36(6), 831-850. doi:10.1002/smj.2015.36.issue-6

Henderson, R., \& Clark, K. B. (1990). Architectural innovation: The reconfiguration of existing product technologies and the failure od established firms. Administrative Science Quarterly, 35(1), 9-30. doi:10.2307/2393549 
Herrmann, P., \& Nadkarni, S. (2014). Managing strategic change: The duality of CEO personality. Strategic Management Journal, 35(9), 1318-1342. doi:10.1002/ smj.2156

Hisrich, R. D., \& Brush, C. G. (1986). The woman entrepreneur: Starting, financing, and managing a successful new business. Lexington, MA: Lexington Books.

Hmieleski, K. M., \& Baron, R. A. (2008a). Regulatory focus and new venture performance: A study of entrepreneurial opportunity exploitation under conditions of risk versus uncertainty. Strategic Entrepreneurship Journal, 2(4), 285-301. doi:10.1002/sej.56

Hmieleski, K. M., \& Baron, R. A. (2008b). When does entrepreneurial self-efficacy enhance versus reduce firm performance. Strategic Entrepreneurship Journal, 2(1), 57-72. doi:10.1002/sej.42

Hmieleski, K. M., \& Corbett, A. C. (2008). The contrasting effects of improvisational behavior with entrepreneurial self-efficacy on new venture performance and entrepreneur work satisfaction. Journal of Business Venturing, 23(4), 482-496. doi:10.1016/j.jbusvent.2007.04.002

Hodgkinson, G. P., \& Healey, M. P. (2011). Psychological foundations of dynamic capabilities: Reflexion and reflection in strategic management. Strategic Management Journal, 32 (13), 1500-1516. doi:10.1002/smj.964

Igra, A. (1979). On forming variable set composites to summarize a block recursive model. Social Science Research, 8(3), 253-264. doi:10.1016/0049-089X(79)90003-6

Inzana, C. M., Driskell, J. E., Salas, E., \& Johnston, J. H. (1996). Effects of preparatory information on enhancing performance under stress. Journal of Applied Psychology, 81 (4), 429-435.

Izard, C. E. (1993). Four systems for emotion activation: Cognitive and noncognitive processes. Psychological Review, 100(1), 68-90.

Jennings, D. F., \& Lumpkin, J. R. (1992). Insights between environmental scanning activities and Porter's generic strategies: An empirical analysis. Journal of Management, 18(4), 791-803. doi:10.1177/014920639201800411

Judge, T. A., \& Bono, J. E. (2001). Relationship of core self-evaluations traits-selfesteem, generalized self-efficacy, locus of control, and emotional stabilitywith job satisfaction and job performance: A meta-analysis. Journal of Applied Psychology, 86(1), 80-92.

Judge, T. A., Jackson, C. L., Shaw, J. C., Scott, B. A., \& Rich, B. L. (2007). Self-efficacy and work-related performance: The integral role of individual differences. Journal of Applied Psychology, 92(1), 107-127. doi:10.1037/0021-9010.92.1.107

Kaplowitz, M., Hadlock, T., \& Levine, R. (2004). A comparison of web and mail survey response rates. Public Opinion Quarterly, 68, 94-101. doi:10.1093/poq/nfh006

Karademas, E. C., Kafetsios, K., \& Sideris, G. D. (2007). Optimism, self-efficacy and information processing of threat-and well-being-related stimuli. Stress and Health, 23(5), 285-294. doi:10.1002/smi.1147

Katila, R. (2002). New product search over time: Past ideas in their prime? Academy of Management Journal, 45(5), 995-1010. doi:10.5465/3069326 
Keinan, G. (1987). Decision making under stress: Scanning of alternatives under controllable and uncontrollable threats. Journal of Personality and Social Psychology, 52(3), 639-644.

Kickul, J., \& Gundry, L. K. (2002). Prospecting for strategic advantage: The proactive entrepreneurial personality and small firm innovation. Journal of Small Business Management, 40(2), 85-97. doi:10.1111/1540-627X.00042

Kim, J. Y. J., \& Miner, A. S. (2007). Vicarious learning from the failures and nearfailures of others: Evidence from the US commercial banking industry. Academy of Management Journal, 50(3), 687-714. doi:10.5465/amj.2007.25529755

Kor, Y. Y., \& Mesko, A. (2013). Dynamic managerial capabilities: Configuration and orchestration of top executives' capabilities and the firm's dominant logic. Strategic Management Journal, 34(2), 233-244. doi:10.1002/smj.2013.34.issue-2

Lazarus, R. S., \& Folkman, S. (1984). Stress, appraisal, and coping. New York, NY: Springer.

Leblebici,H., Salancik, G., Copay, A., \& King, T. (1991). Institutional change and the transformation of interorganizational fields: An organizational history of the U.S. radio broadcasting industry. Administrative Science Quarterly, 36(3), 333-363. doi: $10.2307 / 2393200$

Leifer, R., \& Delbecq, A. (1978). Organizational/environmental interchange: A model of boundary spanning activity. Academy of Management Review, 3(1), 40-50.

Litt, M. D. (1988). Cognitive mediators of stressful experience: Self-efficacy and perceived control. Cognitive Therapy and Research, 12(3), 241-260. doi:10.1007/ BF01176188

Lovelace, J. B., Bundy, J., Hambrick, D. C., \& Pollock, T. G. (2018). The shackles of CEO celebrity: Sociocognitive and behavioral role constraints on "star" leaders. Academy of Management Review, 43(3), 419-444. doi:10.5465/amr.2016.0064

Lumpkin, G. T., \& Dess, G. G. (1996). Clarifying the entrepreneurial orientation construct and linking it to performance. Academy of Management Review, 21(1), 135-172. doi:10.5465/amr.1996.9602161568

Lumpkin, G. T., \& Dess, G. G. (2001). Linking two dimensions of entrepreneurial orientation to firm performance: The moderating role of environment and industry life cycle. Journal of Business Venturing, 16(5), 429-451. doi:10.1016/ S0883-9026(00)00048-3

Mannor, M. J., Wowak, A. J., Bartkus, V. O., \& Gomez-Mejia, L. R. (2016). Heavy lies the crown? How job anxiety affects top executive decision making in gain and loss contexts. Strategic Management Journal, 37(9), 1968-1989. doi:10.1002/ smj.2425

March, J. G., \& Olsen, J. P. (1976). Ambiguity and choice in organizations. Oslo, Bergen, Norway: Universitetsforlaget.

Miller, D. (1983). The correlates of entrepreneurship in three types of firms. Management Science, 29(7), 770-791. doi:10.1287/mnsc.29.7.770

Miller, D. (1991). Stale in the saddle: CEO tenure and the match between organization and environment. Management Science, 37(1), 34-52. doi:10.1287/ mnsc.37.1.34 
Miller, D., Le Breton-Miller, I., Amore, M. D., Minichilli, A., \& Corbetta, G. (2017). Institutional logics, family firm governance and performance. Journal of Business Venturing, 32(6), 674-693. doi:10.1016/j.jbusvent.2017.08.001

Mintzberg, H. (1968). The manager at work; determining his activities, roles, and programs by structured observation. Cambridge, MA: Massachusetts Institute of Technology.

Nadkarni, S., \& Herrmann, P. (2010). CEO personality, strategic flexibility, and firm performance: The case of the Indian business process outsourcing industry. Academy of Management Journal, 53(5), 1050-1073. doi:10.5465/ amj.2010.54533196

Nag, R., \& Gioia, D. A. (2012). From common to uncommon knowledge: Foundations of firm-specific use of knowledge as a resource. Academy of Management Journal, 55(2), 421-457. doi:10.5465/amj.2008.0352

Naldi, L., Nordqvist, M., Sjöberg, K., \& Wiklund, J. (2007). Entrepreneurial orientation, risk taking, and performance in family firms. Family Business Review, 20(1), 33-47. doi:10.1111/j.1741-6248.2007.00082.x

Navis, C., \& Ozbek, O. V. (2016). The right people in the wrong places: The paradox of entrepreneurial entry and successful opportunity realization. Academy of Management Review, 41(1), 109-129. doi:10.5465/amr.2013.0175

Neville, F., Orser, B. J., Riding, A. L., \& Jung, O. (2014). Do young firms owned by recent immigrants outperform other young firms? Journal of Business Venturing, 29(1), 55-71. doi:10.1016/j.jbusvent.2012.10.005

Parker, S. K., \& Collins, C. G. (2010). Taking stock: Integrating and differentiating multiple proactive behaviors. Journal of Management, 36(3), 633-662. doi:10.1177/0149206308321554

Parker, S. K., \& Sprigg, C. A. (1999). Minimizing straing and maximizing learning: The role of job demands, job control, and proactive personality. Journal of Applied Psychology, 84 (6), 925-939.

Peterson, R. S., Smith, D. B., Martorana, P. V., \& Owens, P. D. (2003). The impact of chief executive officer personality on top management team dynamics: One mechanism by which leadership affects organizational performance. Journal of Applied Psychology, 88 (5), 795-808. doi:10.1037/0021-9010.88.5.795

Pryor, C., Webb, J. W., Ireland, R. D., \& Ketchen, D. J. (2016). Toward an integration of the behavioral and cognitive influences on the entrepreneurship process. Strategic Entrepreneurship Journal, 10(1), 21-42. doi:10.1002/sej.1204

Reus, T. H., Ranft, A. L., Lamont, B. T., \& Adams, G. L. (2009). An interpretive systems view of knowledge investments. Academy of Management Review, 34(3), 382-400. doi:10.5465/amr.2009.40631556

Salvato, C., \& Rerup, C. (2011). Beyond collective entities: Multilevel research on organizational routines and capabilities. Journal of Management, 37(2), 468-490.

Schaubroeck, J. M., Hannah, S. T., Avolio, B. J., Kozlowski, S. W., Lord, R. G., Trevino, L. K., ... Peng, A. C. (2012). Embedding ethical leadership within and across organization levels. Academy of Management Journal, 55(5), 1053-1078. doi:10.5465/amj.2011.0064 
Schwandt, D. R. (2005). When managers become philosophers: Integrating learning with sensemaking. Academy of Management Learning \& Education, 4(2), 176-192. doi:10.5465/amle.2005.17268565

Schwoerer, C. E., May, D. R., Hollensbe, E. C., \& Mencl, J. (2005). General and specific self-efficacy in the context of a training intervention to enhance performance expectancy. Human Resource Development Quarterly, 16(1), 111-129. doi:10.1002/(ISSN)1532-1096

Shane, S. (2000). Prior knowledge and the discovery of entrepreneurial opportunities. Organization Science, 11(4), 448-469. doi:10.1287/ orsc.11.4.448.14602

Shane, S., Locke, E. A., \& Collins, C. J. (2003). Entrepreneurial motivation. Human Resource Management Review, 13(2), 257-279. doi:10.1016/ S1053-4822(03)00017-2

Shepherd, D., \& Wiklund, J. (2009). Are we comparing apples with apples or apples with oranges? Appropriateness of knowledge accumulation across growth studies. Entrepreneurship Theory and Practice, 33(1), 105-123. doi:10.1111/ etap.2009.33.issue-1

Short, J. C., McKelvie, A., Ketchen, D. J., \& Chandler, G. N. (2009). Firm and industry effects on firm performance: A generalization and extension for new ventures. Strategic Entrepreneurship Journal, 3(1), 47-65. doi:10.1002/sej.v3:1

Slater, S. F., \& Narver, J. C. (1995). Market orientation and the learning organization. Journal of Marketing, 59(3), 63-74. doi:10.1177/002224299505900306

Sleptsov, A., \& Anand, J. (2008). Exercising entrepreneurial opportunities: The role of information-gathering and information-processing capabilities of the firm. Strategic Entrepreneurship Journal, 2(4), 357-375. doi:10.1002/sej.60

Stajkovic, A. D., \& Luthans, F. (1998). Self-efficacy and work-related performance: A meta-analysis. Psychological Bulletin, 124(2), 240-261. doi:10.1037/0033-2909.124.2.240

Subramaniam, M., \& Youndt, M. A. (2005). The influence of intellectual capital on the types of innovative capabilities. Academy of Management Journal, 48(3), 450-463. doi:10.5465/amj.2005.17407911

Swaminathan, A. (1998). Entry into new market segments in mature industries: Endogenous and exogenous segmentation in the U.S. brewing industry. Strategic Management Journal, 19(4), 389-404. doi:10.1002/(ISSN)1097-0266

Teece, D. J. (2007). Explicating dynamic capabilities: the nature and microfoundations of (sustainable) enterprise performance. Strategic Management Journal, 28(13), 1319-1350. doi:10.1002/(ISSN)1097-0266

Teece, D. J. (2014). The foundations of enterprise performance: Dynamic and ordinary capabilities in an (economic) theory of firms. Academy of Management Perspectives, 28 (4), 328-352. doi:10.5465/amp.2013.0116

Teece, D. J., Pisano, G., \& Shuen, A. (1997). Dynamic capabilities and strategic management. Strategic Management Journal, 18(7), 509-533. doi:10.1002/ (ISSN)1097-0266 
Thomas, J. B., Clark, S. M., \& Gioia, D. A. (1993). Strategic sensemaking and organizational performance: Linkages among scanning, interpretation, action, and outcomes. Academy of Management Journal, 36(2), 239-270. doi:10.2307/256522

Thornhill, S., \& Amit, R. (2003). Learning about failure: Bankruptcy, firm age, and the resource-based view. Organization Science, 14(5), 497-509. doi:10.1287/ orsc.14.5.497.16761

Tsoukas, H. (2011). Representation, signification, improvisation-A threedimensional view of organizational knowledge. In E. Canary \& R. D. McPhee (Eds.), Communication and organizational knowledge: Contemporary issues for theory and practice (pp. xi-xix). New York, NY: Routledge.

Tushman, M. L., \& Anderson, P. (1986). Technological discontinuities and organizational environments. Administrative Science Quarterly, 31(3), 439-465. doi:10.2307/2392832 Venkatraman, N. (1989). Strategic orientation of business enterprises: The construct, dimensionality, and measurement. Management Science, 35(8), 942-962. doi:10.1287/mnsc.35.8.942

Wasserman, N. (2003). Founder-CEO succession and the paradox of entrepreneurial success. Organization Science, 14(2), 149-172. doi:10.1287/orsc.14.2.149.14995

Weick, K. E. (1979). The social psychology of organizing. Reading, MA: Addison-Wesley.

Wiseman, R. (2009). On the use and misuse of ratios in strategic management research. In D. D. Dergh \& D. J. Ketchen (Eds.), Research in the methodology in strategy and management (Vol. 5, pp. 75-110). Bingley, UK: Emerald.

Wood, R., \& Bandura, A. (1989). Social cognitive theory or organizational management. Academy of Management Review, 14(3), 361-384. doi:10.5465/ amr.1989.4279067

Wooldridge, J. M. (2009). Introductory econometrics: A modern approach (4th ed.) Mason, OH: South-Western Cengage Learning.

Yoo, S.-J. (2001). Entrepreneurial orientation, environmental scanning intensity, and firm performance in technology-based SMEs. In W.D. Bygrave, C.G. Brush, P. Davidsson, G.P. Green, P.D. Reynolds, \& H.J. Sapienca (Eds.), Frontiers of Entrepreneurship Research (pp. 365-367). Wellesley, MA: Babson College.

Zahra, S. A. (1991). Predictors and financial outcomes of corporate entrepreneurship: An exploratory study. Journal of Business Venturing, 6(4), 259285. doi:10.1016/0883-9026(91)90019-A

Zhao, H., Seibert, S. E., \& Hills, G. E. (2005). The mediating role of self-efficacy in the development of entrepreneurial intentions. Journal of Applied Psychology, 90(6), 1265-1272. doi:10.1037/0021-9010.90.6.1265

Zimmerman, M. A., \& Zeitz, G. J. (2002). Beyond survival: Achieving new venture growth by building legitimacy. Academy of Management Review, 27(3), 414-431. doi:10.5465/amr.2002.7389921

Zollo, M., \& Winter, S. G. (1999). From organizational routines to dynamic capabilities, Working paper, The Wharton School, Philadelphia.

Zollo, M., \& Winter, S. G. (2002). Deliberate learning and the evolution of dynamic capabilities. Organization Science, 13(3), 339. doi:10.1287/orsc.13.3.339.2780 